\title{
The Phytochemical Analysis of Vinca L. Species Leaf Extracts Is Correlated with the Antioxidant, Antibacterial, and Antitumor Effects
}

\author{
Alexandra Ciorîță ${ }^{1,2, *(\mathbb{D})}$, Cezara Zăgrean-Tuza ${ }^{3}$, Augustin C. Moț ${ }^{3}$, Rahela Carpa ${ }^{1}\left(\mathbb{D}\right.$ and Marcel Pârvu ${ }^{1}(\mathbb{D}$ \\ 1 Faculty of Biology and Geology, Babeș-Bolyai University, 44 Republicii St., 400015 Cluj-Napoca, Romania; \\ rahela.carpa@ubbcluj.ro (R.C.); marcel.parvu@ubbcluj.ro (M.P.) \\ 2 National Institute for Research and Development of Isotopic and Molecular Technologies, 67-103 Donath St., \\ 400293 Cluj-Napoca, Romania \\ 3 Faculty of Chemistry and Chemical Engineering, Babeș-Bolyai University, 11 Arany János St., \\ 400028 Cluj-Napoca, Romania; cezarazt7@gmail.com (C.Z.-T.); augustin.mot@ubbcluj.ro (A.C.M.) \\ * Correspondence: alexandra.ciorita@itim-cj.ro; Tel.: +40-264-584-037
}

Citation: Ciorîță, A.; Zăgrean-Tuza, C.; Moț, A.C.; Carpa, R.; Pârvu, M.

The Phytochemical Analysis of Vinca L. Species Leaf Extracts Is Correlated with the Antioxidant, Antibacterial, and Antitumor Effects. Molecules 2021, 26, 3040. https://doi.org/ $10.3390 /$ molecules 26103040

Academic Editor: Raffaele Capasso

Received: 28 April 2021

Accepted: 16 May 2021

Published: 19 May 2021

Publisher's Note: MDPI stays neutral with regard to jurisdictional claims in published maps and institutional affiliations.

Copyright: (c) 2021 by the authors. Licensee MDPI, Basel, Switzerland. This article is an open access article distributed under the terms and conditions of the Creative Commons Attribution (CC BY) license (https:/ / creativecommons.org/licenses/by/ $4.0 /)$.

\begin{abstract}
The phytochemical analysis of Vinca minor, V. herbacea, V. major, and V. major var. variegata leaf extracts showed species-dependent antioxidant, antibacterial, and cytotoxic effects correlated with the identified phytoconstituents. Vincamine was present in $V$. minor, V. major, and V. major var. variegata, while $V$. minor had the richest alkaloid content, followed by $V$. herbacea. $V$. major var. variegata was richest in flavonoids and the highest total phenolic content was found in $V$. herbacea which also had elevated levels of rutin. Consequently, $V$. herbacea had the highest antioxidant activity followed by $V$. major var. variegata. Whereas, the lowest one was of $V$. major. The $V$. minor extract showed the most efficient inhibitory effect against both Staphylococcus aureus and E. coli. On the other hand, $V$. herbacea had a good anti-bacterial potential only against $S$. aureus, which was most affected at morphological levels, as indicated by scanning electron microscopy. The Vinca extracts acted in a dose-depended manner against HaCaT keratinocytes and A375 melanoma cells and moreover, with effects on the ultrastructure, nitric oxide concentration, and lactate dehydrogenase release. Therefore, the Vinca species could be exploited further for the development of alternative treatments in bacterial infections or as anticancer adjuvants.
\end{abstract}

Keywords: alkaloids; vincamine; antioxidant; antibacterial; phenolic compounds

\section{Introduction}

The progress of modern medicine in the last century is the result of multiple, relentless battles fought against environmental and inborn threats against humans. The diseases associated with these harmful factors had driven the efforts of researchers and physicians toward the modern medicine practices, that are frequently updated. Antibiotic-resistant bacteria and invasive malignant tumors are two of the most challenging, contemporary problems that scientists are constantly attempting to overcome [1,2]. Since the gene for antibiotic resistance in bacteria was identified to be present also in an ancient strain [3], far before antibiotics were even discovered, resources were increasingly directed towards alternative means of treatment $[4,5]$. At the same time, chemotherapeutic drugs remain the main treatment administered in cancer patients, even if the side effects are well-known and thoroughly documented [6]. Given the above-mentioned difficulties that are encountered along with the evolution of therapeutics, scientists concentrated their attention on phytotherapy [7].

Plants are the foundation of modern medicine, as they synthesize natural products with effective antibacterial [8], antifungal [9], antiparasitic [10], and antitumor [11] activities. Among these medicinal plants are also the Vinca species. The United States Department of Agriculture [12] describes three species and one variety for the Vinca genus: V. major L., 
V. minor L., V. herbacea Walds. and Kit., and V. major L. var. variegata 'Louden'. The European Environment Agency [13] includes several V. major synonyms (V. erecta Regel and Schmalh, $V$. pubescens d'Urv) in their database and treats $V$. difformis Pourret as an independent species. In his work, Koyuncu (2012) identified and described a new species (Vinca soneri Koyuncu) [14], which is currently included only in the Plants of the World database [15].

These plants had been intensely studied for their therapeutic properties $[16,17]$, due to the rich alkaloid content [18-21]. Moreover, a relation between the morphological and ultrastructural aspects of the leaf in Vinca species, and the chemical composition is yet to be established [22]. Vinca alkaloids belong to the terpene indole type with more than 50 described only for $V$. minor [23,24]. Distinct types of Vinca alkaloids have similar structures, but their mode of action and toxicological profiles vary extensively [25].

The first isolation of a Vinca alkaloid was made by Lucas in 1859, and since then the research continued along the centuries [26]. In the early 1900's, Vinca species were still insufficiently studied, and three new alkaloids were described for $V$. minor and three for $V$. herbacea [27-29]. Later, 43 alkaloids were isolated from $V$. major, 40 from $V$. minor and three from $V$. herbacea. After 2010 and up until now, new alkaloids are discovered and isolated almost every year only for $V$. minor, nine new alkaloids were described and isolated from $V$. major and two from $V$. herbacea $[19,20,27,30,31]$.

One of the most important alkaloids of the Vinca species is vincamine [32] recognized as one of the few alkaloids that has beneficial effects on living cells [33]. Unlike other alkaloids found in the Vinca species analyzed herein, vincamine is commercially available and included in dietary supplements, but the currently used active compound (vinpocetine) is a semi-synthetic one, derived from vincamine [34-36]. Vincamine is most abundant in $V$. minor and acts as a cerebral metabolic enhancer by extending the blood flow and regional glucose uptake, is a neuroprotective against ischemia and hypoxia, and has antioxidant and antiapoptotic properties [37,38]. For example, Wang et al. (2020) designed and synthesized several drugs from vincamine, which inhibited apoptosis in pancreatic $\beta$-cells in a dose-dependent manner [39].

Along alkaloids, other important natural compounds found in Vinca species are phenolic acids, carotenoids, caffeic acid, iridoids, flavonoids, amino acids, and other phenolic compounds $[16,40]$. One phenol that seems to stand out in high amounts throughout the Vinca family is chlorogenic acid, which is considered as a marker for leaf epidermis metabolites [41]. Other phenols have also been identified in various Vinca species, in far lesser concentrations compared to chlorogenic acid, such as $p$-coumaric acid, caffeic acid, ferulic acid, rutin, and kaempferol [42,43].

The aim of this study was to compare the leaf extracts of Vinca minor, V. major, $V$. herbacea, and $V$. major var. variegata in terms of chemical composition, antibacterial activity against $E$. coli and S. aureus, and cytotoxic effects against normal keratinocytes (HaCaT) and skin melanoma (A375) human cell lines. Therefore, a correlation between the observed effects in the assayed cells and the phytoconstituents was established, herein, such as: Alkaloids, flavonoids, hydroxybenzoic, or hydroxycinnamic acids. For the first time, these species were investigated together and comparatively, showing that the least familiar Vinca species have a great antioxidant, antitumoral, and antibacterial potential and could be exploited further for their therapeutic properties. As a novel approach, the total alkaloid content was determined in the selected species through an adapted Dragendorff assay successfully optimized in this study. Additionally, the morphological effects of the extracts against Gram-negative and Gram-positive bacteria, along with the ultrastructural modifications induced in human cell lines were described using scanning and transmission electron microscopy techniques.

New-generation drugs combine strong antibiotics or cytostatics with natural products found in plants, thus, this study could be the foundation for new research opportunities by exploiting other Vinca species with good potential in further, and more advanced investigations. 


\section{Results}

\subsection{Phytochemical Analyses \\ HPLC-DAD Method}

HPLC analysis of all four extracts were performed with corresponding chromatograms (Figure 1a). Twenty common standards were chosen, comprising a relatively wide array of plant natural compounds, with representatives in flavonoids, hydroxybenzoic acids, hydroxycinnamic acids, as well as alkaloid groups. Integration of peaks larger than $10 \mathrm{mAbs}$ yielded the results shown in Table 1. All extracts exhibited high levels of chlorogenic acid, whereas $V$. herbacea had a remarkable high content of rutin. Other flavonoids such as quercetin and quercitrin were found, although in lower concentrations. Vincamine was found only in V. minor, V. major, and V. major var. variegata.

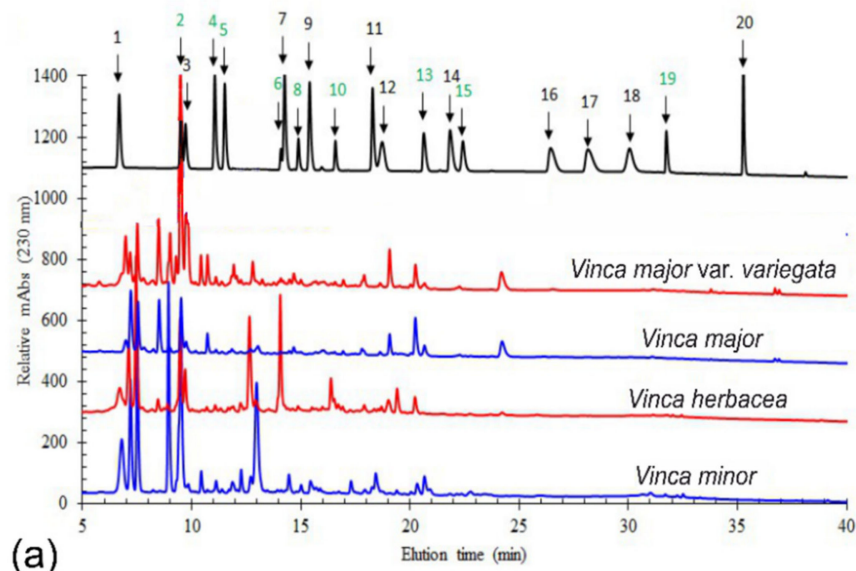

(a)

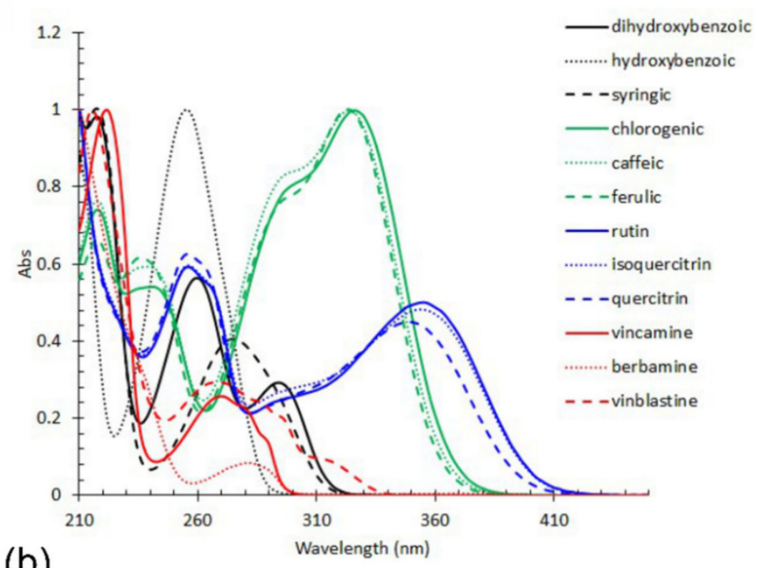

(b)

Figure 1. (a) HPLC-DAD chromatograms of the Vinca minor, V. major, V. major var. variegata, and V. herbacea plant extracts monitored at $230 \mathrm{~nm}$. Chromatogram of analytical standards includes: (1) 3,4-dihydroxybenzoic acid, (2) chlorogenic acid, (3) 4-hydroxybenzoic acid, (4) caffeic acid, (5) syringic acid, (6) rutin, (7) p-coumaric acid, (8) isoquercitrin, (9) ferulic acid, (10) quercitrin, (11) myricetin, (12) berbamine, (13) vincamine, (14) jatrorrhizine, (15) quercetin, (16) palmatine, (17) berberine, (18) kaempferol, (19) vinblastine, and (20) galangin. The identified compounds in the studied Vinca species are marked in green in the upper chromatogram; (b) UV molecular absorption spectra as registered by the DAD detector for the representative standards from each main phytochemical group (grey-hydroxybenzoic acids, green-cinnamic acids, blue-flavonoids, and red-alkaloids).

Table 1. Concentration of the main phytoconstituents identified in the Vinca minor, V. major, V. major var. variegata, and $V$. herbacea leaf extracts as determined and calculated from HPLC chromatograms.

\begin{tabular}{lcccc}
\hline \multirow{2}{*}{ Compound } & \multicolumn{4}{c}{ Compound Concentration Expresses in $\mu \mathrm{g} / \mathrm{g}$} \\
\cline { 2 - 5 } & V. minor & V. major & V. major var. variegata & V. herbacea \\
\hline Chlorogenic acid & $4112 \pm 13^{* *}$ & $675 \pm 160$ & $932 \pm 260$ & $1538 \pm 200^{*}$ \\
Caffeic acid & $229 \pm 2^{* * *}$ & $13 \pm 2$ & $182 \pm 23^{* *}$ & $13 \pm 1$ \\
Rutin & $73 \pm 1^{* *}$ & $11 \pm 1$ & $94 \pm 10^{* *}$ & $2528 \pm 160^{* * *}$ \\
Isoquercitrin & $12 \pm 1$ & $12 \pm 1$ & $38 \pm 4^{*}$ & $87 \pm 4^{* * *}$ \\
Quercitrin & $52 \pm 4^{*}$ & $11 \pm 1$ & $45 \pm 8^{*}$ & $109 \pm 10^{* * *}$ \\
Vincamine & $65 \pm 1^{* * *}$ & $42 \pm 3$ & $31 \pm 2$ & $\mathrm{n} . \mathrm{d}$. \\
Quercetin & $21 \pm 2$ & $14 \pm 2$ & $28 \pm 2$ & $20 \pm 3$ \\
\hline n.d.- - not detected; ${ }^{* * *} p<0.001^{* *} p<0.01^{*}{ }^{*} p<0.05$ according to Student's $t$ tests.
\end{tabular}

Each class of compounds had specific UV-Vis absorption features (Figure 1b). Flavonoids displayed an absorption maximum between 340 and $380 \mathrm{~nm}$, hydroxybenzoic acids had peaks with absorption maximum between 230 and $320 \mathrm{~nm}$. Whereas hydroxycinnamic acids had a signature spectrum with a peak between 310 and $350 \mathrm{~nm}$, with a shoulder around $300 \mathrm{~nm}$. Alkaloids had also clearly distinct spectral features with an absorption maximum between 240 and $310 \mathrm{~nm}$. 
However, many of the obtained peaks could not be identified. In order to sort this information out, UV-Vis spectra corresponding to all peaks that contributed to more than $1 \%$ to the final area were selected for Principal Component Analysis (PCA) after normalization. UV-Vis spectra of all twenty standards were also included in the analysis as a mean of control.

All spectral features (position of absorption maximum, additional absorption wavelengths, spectral shoulders) constituted the bedrock for cluster formation: Each of the four score-plots (Figure 2a-d) exhibited four identical groups. Two of these groups were distinct, namely those attributed to hydroxycinnamic acids and flavonoids. The groups of alkaloids and hydroxybenzoic acids were slightly superimposed. Retention time, spectral features, phytochemical group, and chromatographic area of each identified spectra/peak can be found in Supplementary Table S1. Representative spectra of PCA grouped compounds are also shown in Supplementary Figure S1. Noteworthy, most of the analyzed peaks of unidentified compounds belonged to alkaloid phytochemical group.
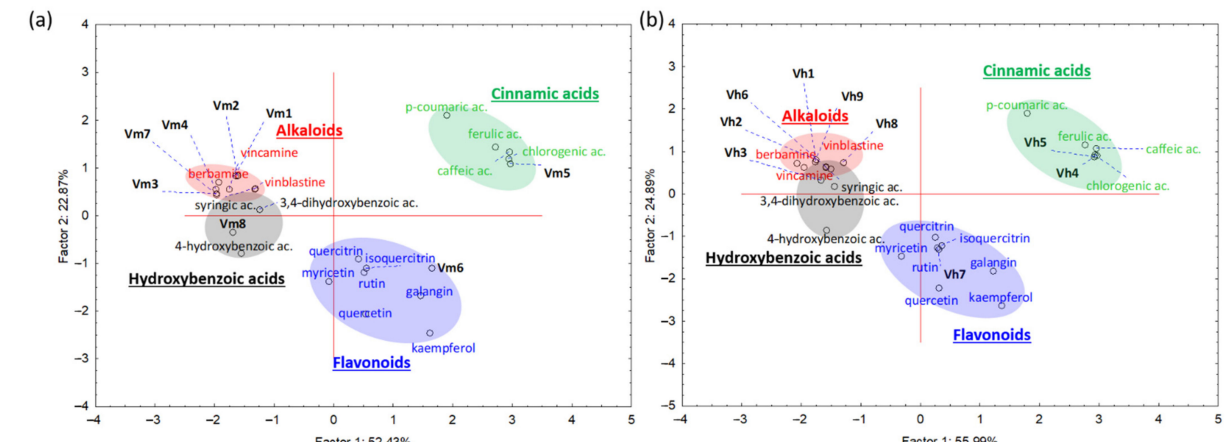

(c)

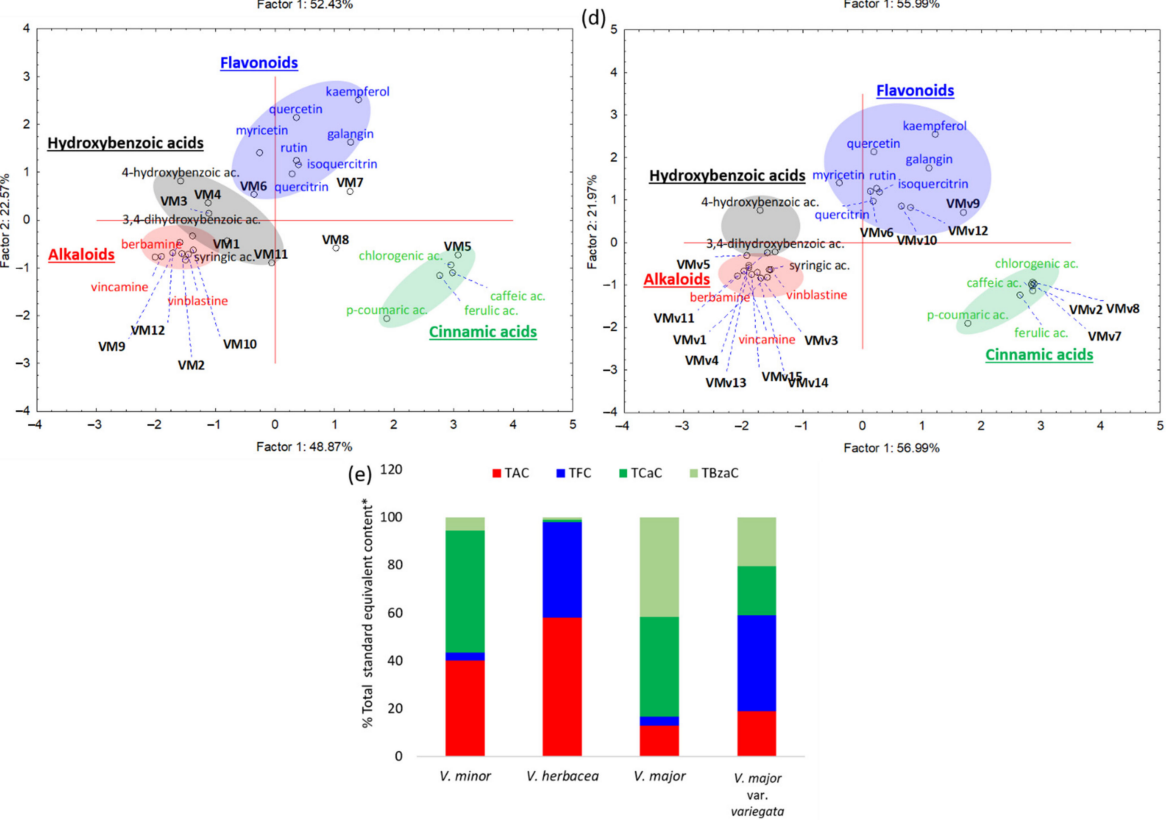

Figure 2. Chemo-mapping of the major chromatographic peaks-phytoconstituents classification-based on spectral similarities for each studied extract using PCA. PCA was applied on exported UV DAD spectra, for each chromatographic peak. Shown here are the scatterplots of the scores for the first two principal components for (a) V. minor, (b) V. herbacea, (c) V. major, and (d) V. major var. variegata. The classified compounds are detailed in Table S1. Groups with high similarity are clustered in specific color for each phytoconstituent group or class (grey-hydroxybenzoic acids, green-cinnamic acids, blue-flavonoids, and red-alkaloids); (e) Total standard (vincamine for TAC, quercetin for TFC, cynnamic acid for TCaC and benzoic acid for TBzaC) equivalent content (\%) for each extract for $230 \mathrm{~nm}$ chromatogram, after PCA classification. TAC-total alkaloid content, TFC-total flavonoid content, TCaC-total cinnamic acids content, TBzaC-total hydroxybenzoic acids content, $\mathrm{Vm}=V$. minor, $\mathrm{VM}=V$. major, $\mathrm{VMv}=V$. major var. variegata, $\mathrm{Vh}=V$. herbacea . 
For all grouped spectra, the total standard equivalent content was calculated for each class of phytoconstituents identified by PCA analysis (alkaloids, flavonoids, hydroxybenzoic, and hydroxycinnamic acids), as presented in Figure 2e. Alkaloid content as determined by HPLC was highest for $V$. herbacea; $V$. major var. variegata and $V$. herbacea were the richest in flavonoids. Data obtained from this set of analyses were further used as a means of comparison for the results obtained by colorimetric determination of total alkaloid content (TAC) and total flavonoid content (TFC).

\subsection{Colorimetric Determination of Total Phenolic and Flavonoid Content}

The content of natural compounds, such as phenols and flavonoids were also determined through a colorimetric assay (Table 2). The total phenolic content (TPC) was highest in $V$. herbacea, whereas flavonoid concentration was most elevated in $V$. major var. variegata, followed by $V$. herbacea. Both $V$. minor and $V$. major displayed relatively low levels of phenols, as well as flavonoids. The calibration curves built for both phytochemical methods (Supplementary Figure S2) had good linearity in the tested concentration interval. A good correlation $(r=0.8)$ was observed between the results obtained by HPLC and those from the colorimetric assay. Additionally, antioxidant activities had a high degree of correlation $(r>0.9)$ with TPC/TFC.

Table 2. Antioxidant activities and phytoconstituent content of Vinca minor, V. major, V. major var. variegata, and V. herbacea leaf extracts expressed as equivalents of standard for each assay.

\begin{tabular}{lcccccc}
\hline \multirow{1}{*}{ Extract } & REAC & CUPRAC & LipPx & TPC & TFC & TAC \\
\cline { 2 - 7 } & mg rutin/g & mg rutin/g & mg rutin/g & mg gallic/g & mg rutin/g & mg vinblastine/g \\
\hline V. minor & $106 \pm 53^{*}$ & $123 \pm 18^{*}$ & $43 \pm 9$ & $51 \pm 0^{*}$ & $29 \pm 1$ & $332 \pm 33^{* * *}$ \\
V. major & $35 \pm 13^{* *}$ & $50 \pm 2$ & $153 \pm 12^{* *}$ & $21 \pm 2$ & $11 \pm 3$ & $35 \pm 11$ \\
V. major var. variegata & $335 \pm 10^{* *}$ & $463 \pm 37^{* *}$ & $229 \pm 20^{* *}$ & $93 \pm 7^{* *}$ & $179 \pm 2^{* * *}$ & $101 \pm 6^{*}$ \\
V. herbacea & $405 \pm 2^{* *}$ & $583 \pm 48^{* *}$ & $267 \pm 23^{* *}$ & $100 \pm 6^{* *}$ & $151 \pm 1^{* *}$ & $195 \pm 9^{* *}$ \\
\hline
\end{tabular}

REAC $=$ rutin equivalent antioxidant capacity, CUPRAC $=$ cupric reducing antioxidant capacity, LipPx $=$ inhibition of induced liposomes peroxidation, TPC $=$ total phenolic content, TFC $=$ total flavonoid content, TAC $=$ total alkaloid content; ${ }^{* * *} p<0.001,{ }^{* *} p<0.01 ;{ }^{*} p<0.05$ according to Student's $t$ test.

\subsection{Determination of Total Alkaloid Content}

The alkaloid content was determined by means of a colorimetric assay using UVVis spectrophotometry. Herein, the Dragendorff method with Munier and Macheboeuf modification (addition of tartaric acid in the reagent) was performed. There are two main differences compared to the original assay. First, the concentration of glacial acetic acid is higher, to determine indole alkaloids as well; second, the bismuth precipitate was not separated, but directly quantified for optical density at $560 \mathrm{~nm}$ (specific wavelength of the precipitate). Based on this working protocol, a calibration curve was built for vinblastine, with a degree of linearity high over 60 units of concentration (Figure 3a). TAC of all four plant extracts was determined using this method, with calculated values of vinblastine equivalents, as presented in Table 2. V. minor, followed by $V$. herbacea, had the highest alkaloid content. TAC obtained from Dragendorff assay was correlated with total alkaloid content from the HPLC results. HPLC results were calculated by addition of areas corresponding to all assigned alkaloids, based on the PCA analysis (Figure 3b). The value of the determined coefficient is very high $(r=0.999)$, indicating a strong correlation between the two methods, pointing out the ability of the used Dragendorff assay for the identification of indole alkaloids. 


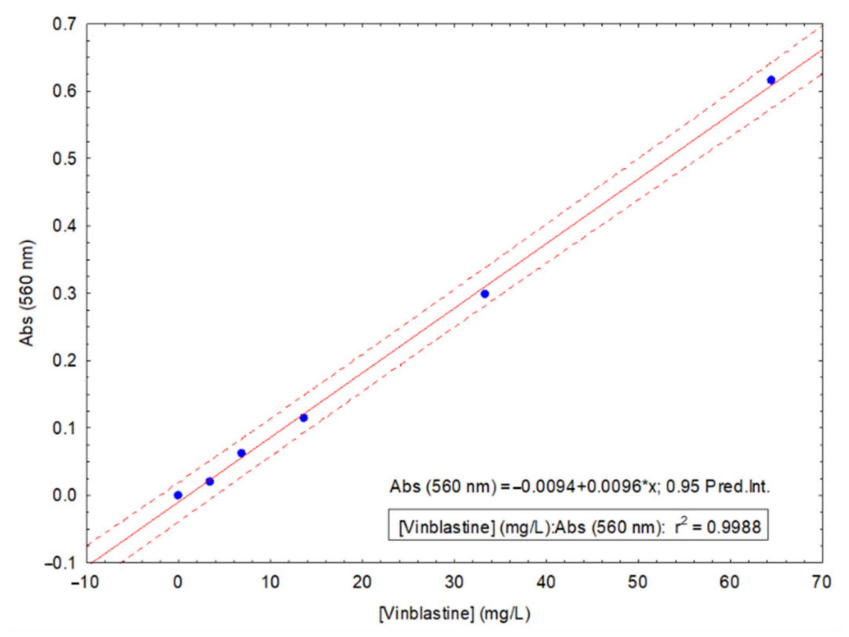

(a)

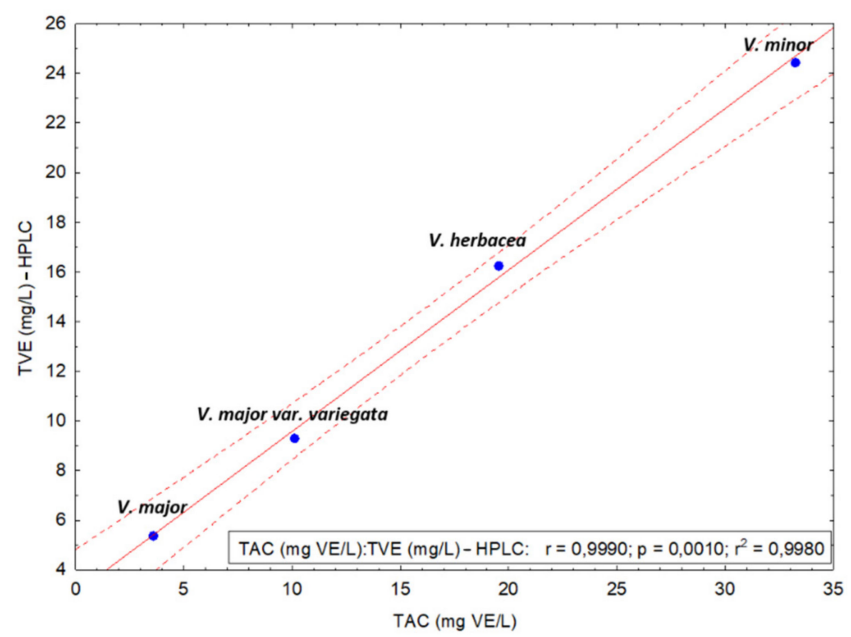

(b)

Figure 3. (a) Calibration curve of the proposed Dragendorff assay with vinblastine as a standard; (b) graphical correlation between Dragendorff TAC and HPLC calculated Total Vincamine Equivalents.

\subsection{Antioxidant Activity}

The antioxidant activity was determined for each diluted extract by three different assays: Rutin equivalent antioxidant capacity (REAC), cupric reducing antioxidant capacity (CUPRAC) and induced peroxidation of liposomes (LipPx). Throughout all three assays, the highest antioxidant activity was observed for $V$. herbacea extract, followed by $V$. major var. variegata, whereas the lowest one was that corresponding to $V$. major. Overall, the results of the applied assays correlated very well (for example, the correlation for REAC and CUPRAC was the highest $(r>0.9))$. Surprisingly, despite the different underlying assay mechanisms (which could give opposite results, depending on the structure of the compounds tested), there was also a high degree of correlation between REAC, CUPRAC, and LipPx $(r>0.75)$. The actual values of rutin equivalents are showed in Table 2. Each one was calculated using the equation fitted for the calibration curve.

\subsection{Antibacterial Activity and Morphological Examination}

The agar well diffusion method revealed that all extracts had a better inhibitory effect against $S$. aureus compared to E. coli (Supplementary Figure S3). The microdilution method confirmed the results from the agar well diffusion method, as growth of $S$. aureus was inhibited by all extract to a greater extent, compared to E. coli $(p<0.0001)$.

E. coli was inhibited by all extracts in a dose-dependent manner. The most efficient of the tested plant extracts was $V$. minor, which inhibited the bacterial growth at all tested concentrations (60\% to $40 \%$ inhibition, Figure $4 a)$. The inhibitory efficiency of $V$. minor extract was followed by $V$. major. On the other hand, $V$. herbacea and $V$. major var. variegata had a proliferative effect on E. coli at concentrations between $0.09-3.12 \%$, as the corresponding optical densities exceeded by almost two-fold those of the untreated control (Figure 4c,d). The growth of $S$. aureus was inhibited in a dose-dependent manner by $V$. minor (Figure 4a) and V. major var. variegata extracts, with similar inhibitory capacities (Figure 4c). The $V$. herbacea extract inhibited the growth of $S$. aureus by $60 \%$, at almost all concentrations (Figure 4d) and V. major (Figure 4b) was the least efficient extract.

A series of relations between alkaloid, phenolic contents and bacterial inhibition efficiency show that phenols are highly effective against $S$. aureus, but induce a proliferative response in E. coli, while the alkaloids can inhibit the E. coli growth, but not the $S$. aureus growth (Supplementary Figure S4). 


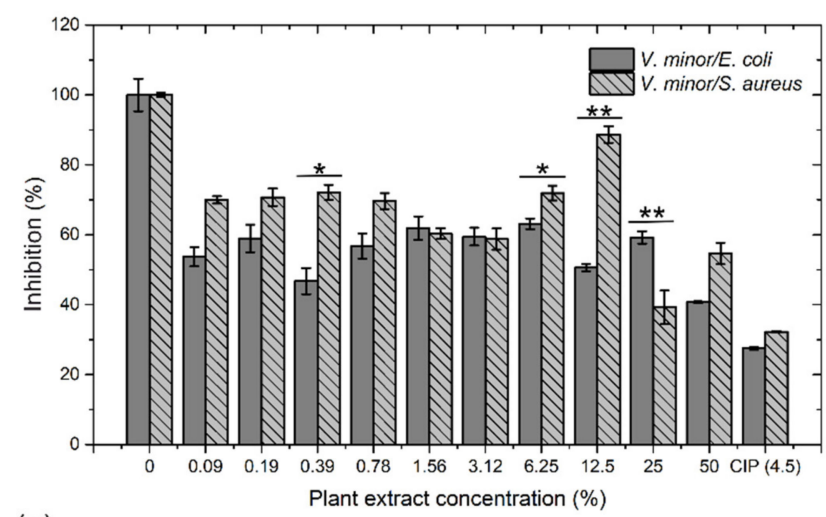

(a)

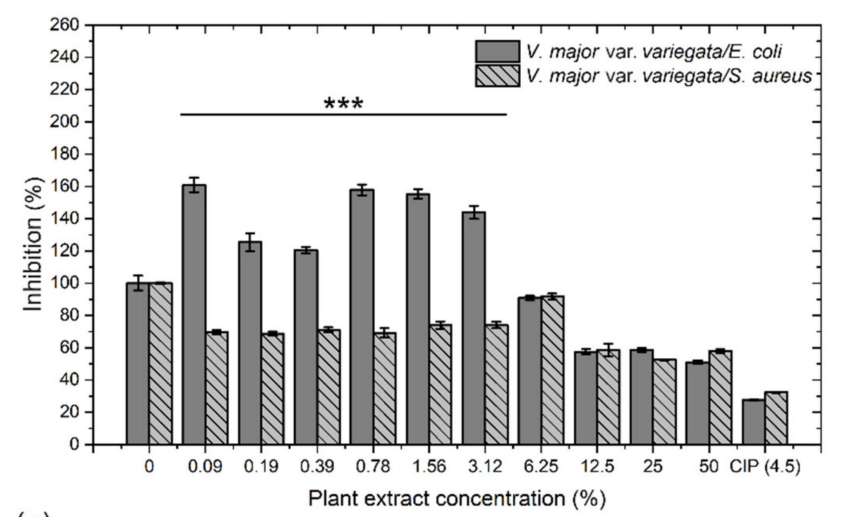

(c)

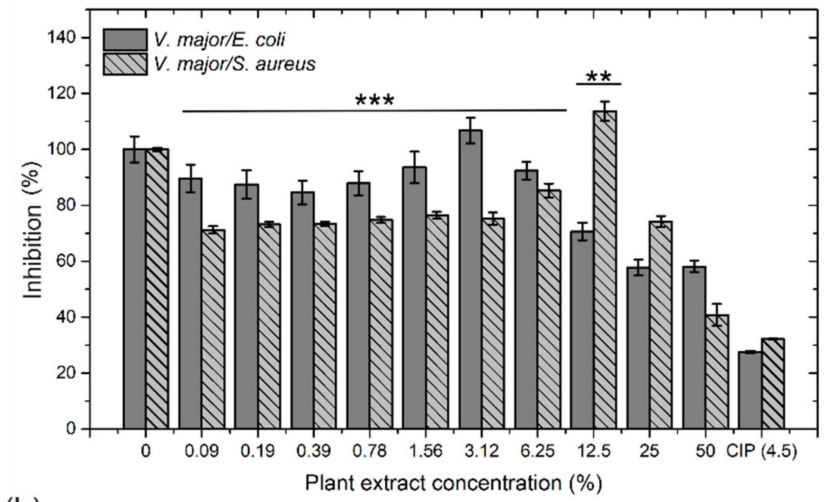

(b)

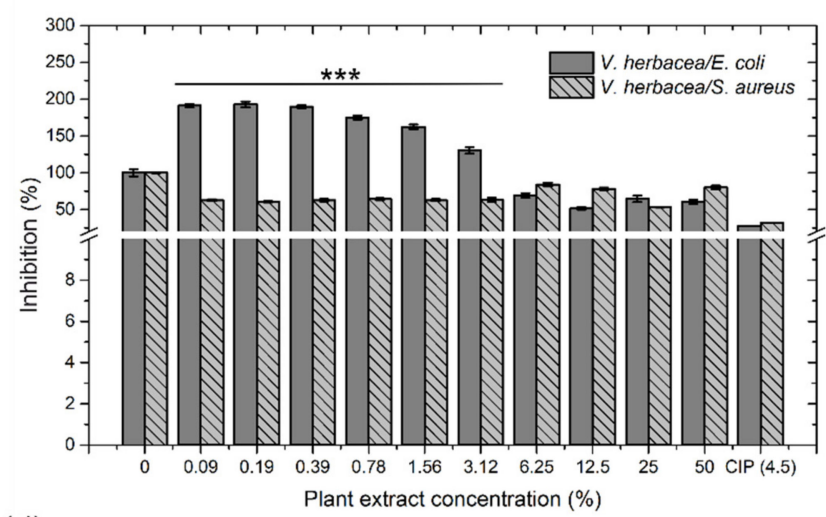

(d)

Figure 4. The antibacterial effect of Vinca minor (a), V. major (b), V. major var. variegata (c), and V. herbacea (d) leaf extracts against $E$. coli and S. aureus, assessed through the microdilutions method. The values represent the mean of at least three independent experiments \pm standard error of the mean (s.e.m.); ${ }^{* *} p<0.0001,{ }^{* *} p<0.001,{ }^{*} p<0.05$ according to one way ANOVA and Student's $t$ tests.

Scanning electron microscopy (SEM) analysis highlighted the morphological alterations in bacterial cells treated with Vinca extracts. E. coli treated with V. major var. variegata had a prominent glycocalyx present on the surface (Supplementary Figure S5), as compared to the untreated control and the other extracts used. S. aureus reacted differently to the tested extracts (Figure 5). The surface of the cocci was smoother in the samples treated with $V$. major and $V$. major var. variegata, while $V$. herbacea had the most destructive effects, with visible signs of degradation. 

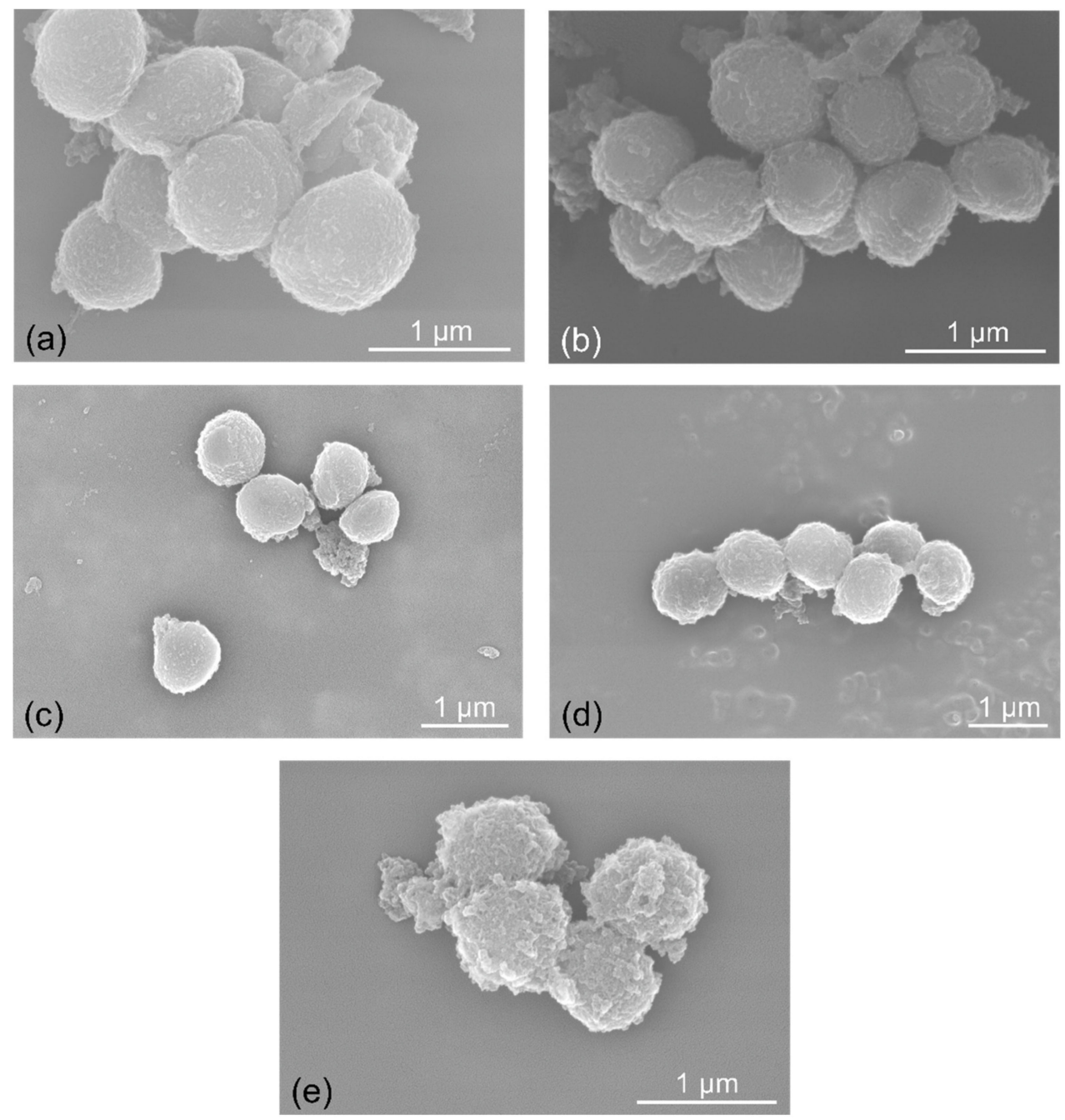

Figure 5. SEM micrographs of the untreated S. aureus strain, (a) and compared to the strains treated with (b) V. minor, (c) V. major, (d) V. major var. variegata, and (e) V. herbacea leaf extracts at Minimal Inhibitory Concentration (MIC).

\subsection{Cytotoxicity Assays and Ultrastructural Examination}

The cell viability was assessed in vitro through 3-(4,5-dimethylthiazol-2-yl)-2,5diphenyltetrazolium bromide solution (MTT) assay on HaCaT keratinocytes and A375 melanoma (Figure 6).

According to ISSO: $10993-5$, the viability is interpreted as following: Within $80-60 \%$, weak cytotoxicity, $60-40 \%$, moderate cytotoxicity, and $<40 \%$, strong cytotoxicity. All extracts reacted in a dose-depended manner and at concentrations below $1 \%$ (and including $2 \%$ for $V$. minor), the extracts had a proliferative effect on the HaCaT cells (viability $>100 \%$ ) but inhibited the A375 cells at all concentrations.

The concentration at which $50 \%$ of the cells are inhibited $\left(\mathrm{IC}_{50}\right)$ was calculated for each extract. These results enabled us to rank the toxicity of the extracts. Thus, for $\mathrm{HaCaT}$ cells, the $V$. minor extract was classified as least toxic (4.25\%), followed by $V$. major $(3.89 \%)$, $V$. herbacea $(2.89 \%)$, and $V$. major var. variegata $(2.85 \%)$. These values are in relation to the above-mentioned results, confirming that $V$. minor was the least toxic extract and $V$. major var. variegata the most toxic one (Figure 6a) against HaCaT cells. Overall, the viability of melanoma cells was affected to higher extents compared to normal keratinocytes (Figure $6 \mathrm{~b}$ ). However, the $\mathrm{IC}_{50}$ values were higher, indicating that higher doses of extracts are needed for cancer cell inhibition, along with longer exposure. V. minor (9\%) was the least toxic extract against A375, as well (Figure 6b), followed by V. major (7.04\%), V. major var. variegata $(2.37 \%)$, and $V$. herbacea $(2.3 \%)$. 

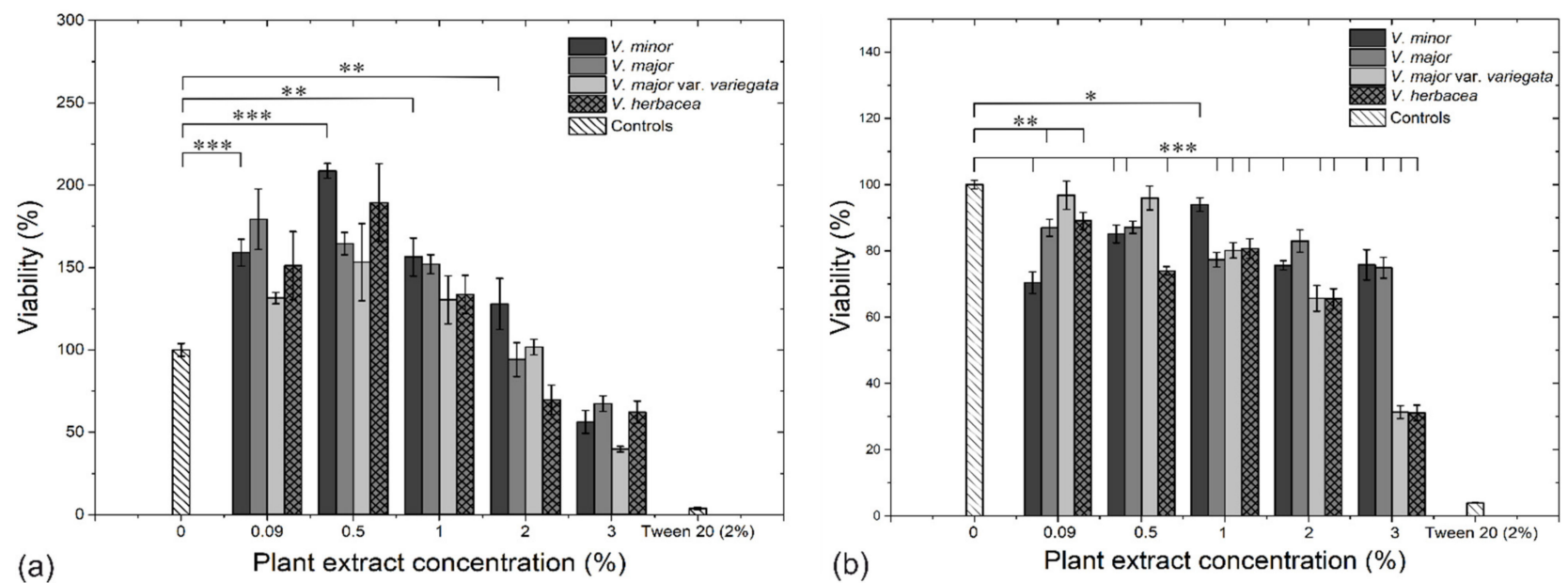

Figure 6. In vitro cytotoxic effects of the Vinca plant extracts used against normal keratinocytes (HaCaT) for $48 \mathrm{~h}$ (a), and skin melanoma cells (A375) at $72 \mathrm{~h}$ (b), compared to a positive control (untreated cells) and a negative control (cells treated with Tween 20 at $2 \%$ concentration); ${ }^{* * *} p<0.0001,{ }^{* *} p<0.001,{ }^{*} p<0.05$ according to one way ANOVA and Student's $t$ tests.

Negative correlations $(p>-0.6)$ were observed between $\mathrm{IC}_{50}$ values and TFC and TPC in both HaCaT and A375 cells (Supplementary Figure S6). This indicates that once the concentration of phenols and flavonoids increase, the value of the $\mathrm{IC}_{50}$ concentration decreases, meaning that these phytoconstituents could be responsible for the cytotoxic effects on human cell lines.

Lactate dehydrogenase (LDH) release into the culture medium is an indicator for cell damage. Depending on the formulae used for calculation, the cell growth inhibition or necrosis could be determined [44]. For $V$. minor a dose-dependent reaction was observed on the $\mathrm{HaCaT}$ cells, while the rest of the extracts generated constant LDH values (Figure 7a). A375 cells were more affected compared to HaCaT cells (Figure 7c), when it comes to LDH release. The values exceeded even those observed for the Tween treated cells, for $V$. herbacea, followed by $V$. minor, but $V$. major and $V$. major var. variegata had also a pronounced negative effect against A375 cells. A negative correlation was observed between LDH release and TAC in HaCaT cells, and a positive correlation was observed in LDH release and TAC and TPC in A375 cells. This indicated that the alkaloids of Vinca species have a destructive effect on the membranes of melanoma cells but not normal cells (Supplementary Figure S7).

High levels of nitric oxide (NO) can often lead to nitrite and nitrate oxidations, eventually inducing oxidative stress in cells [45]. Autoxidation of $\mathrm{NO}$ generates $\mathrm{N}_{2} \mathrm{O}_{3}$, a compound that reacts with sulfanilamide to produce a diazonium ion that is further coupled with $\mathrm{N}$-(-1-napthyl)-ethylenediamine (N1-NAP), forming a product that strongly absorbs at $540 \mathrm{~nm}$ [45]. The Griess reaction was performed in order to determine the NO concentration in the culture medium, after the cells were individually treated with all extracts, for $48 \mathrm{~h}$ (HaCaT), and $72 \mathrm{~h}$ (A375), respectively. For HaCaT cells, a dose-dependent increase in NO concentration was observed for $V$. minor and $V$. major var. variegata. $V$. herbacea generated constantly high values of NO in the medium. Whereas, for $V$. major the values were constantly low, independent of the concentration used (Figure $7 \mathrm{~b}$ ). The NO concentration differed for A375, where high levels were detected for all Vinca extracts at 3\% treatment (Figure 7d). A correlation $(p=8)$ was observed between the NO concentration and TPC and TAC in HaCaT cells that indicates how phenols and alkaloids of Vinca plant extracts influence the oxidation of nitrite and nitrate. Same correlation $(p=8)$ was observed for A375 cells and TAC (Supplementary Figure S7). 

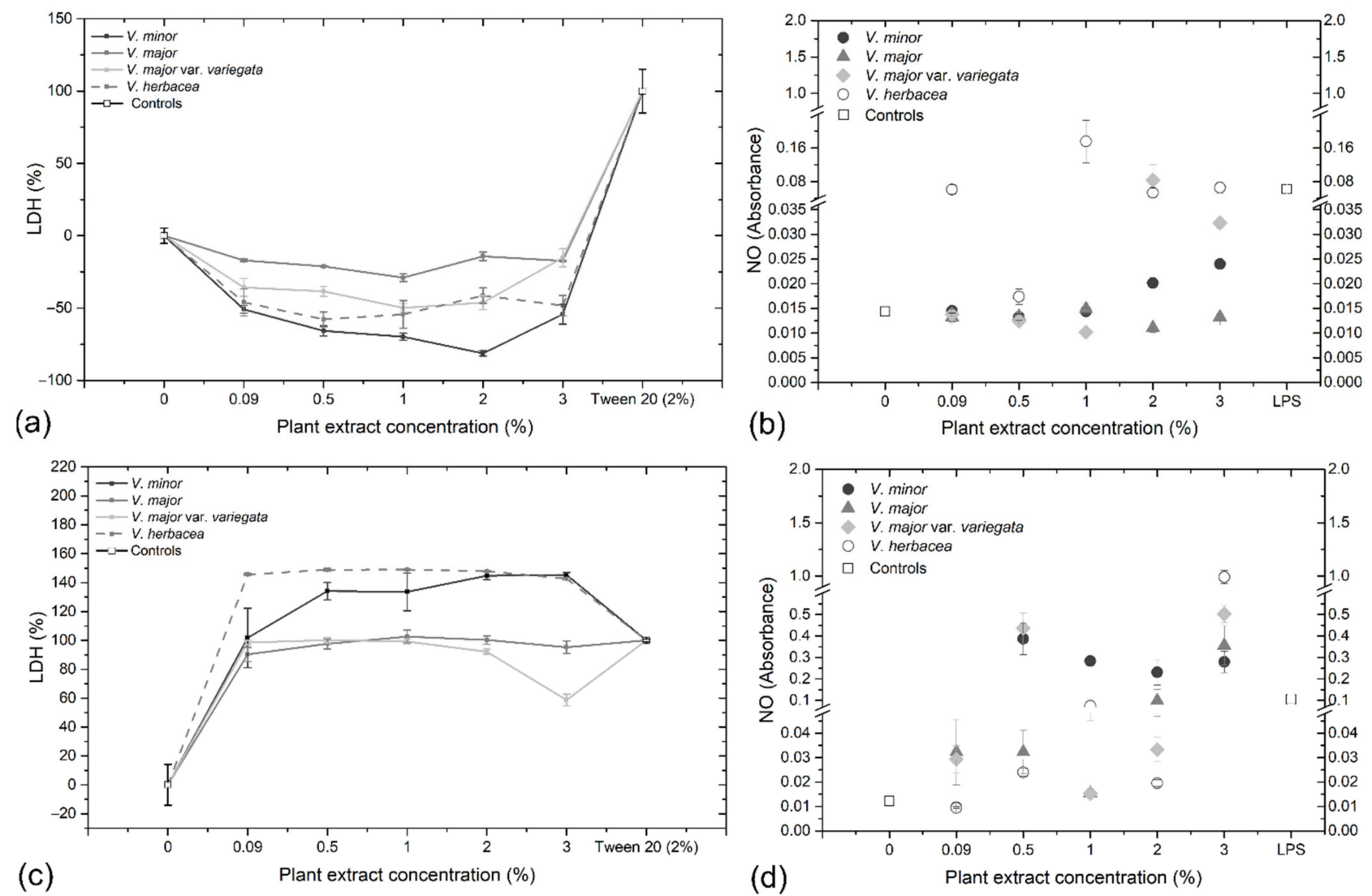

Figure 7. In vitro analysis of $\mathrm{LDH}(\mathbf{a})$ and $\mathrm{NO}(\mathbf{b})$ release in normal keratinocytes $(\mathrm{HaCaT})$ treated with the plant extracts for $48 \mathrm{~h}$ and in vitro analysis of $\mathrm{LDH}$ (c) and $\mathrm{NO}$ (d) release in skin melanoma cells (A375) treated with the Vinca leaf extracts for $72 \mathrm{~h}$; LPS = lipopolysaccharides.

To further explore the effects of the plant extracts, transmission electron microscopy (TEM) analysis was employed to reveal ultrastructural changes in the treated cells. A375 cells treated with $V$. minor extract showed numerous vesicles, while those treated with the rest of the extracts presented a high number of mitochondria (Figure 8). Similar results were observed on the HaCaT cells (Supplementary Figure S8). 

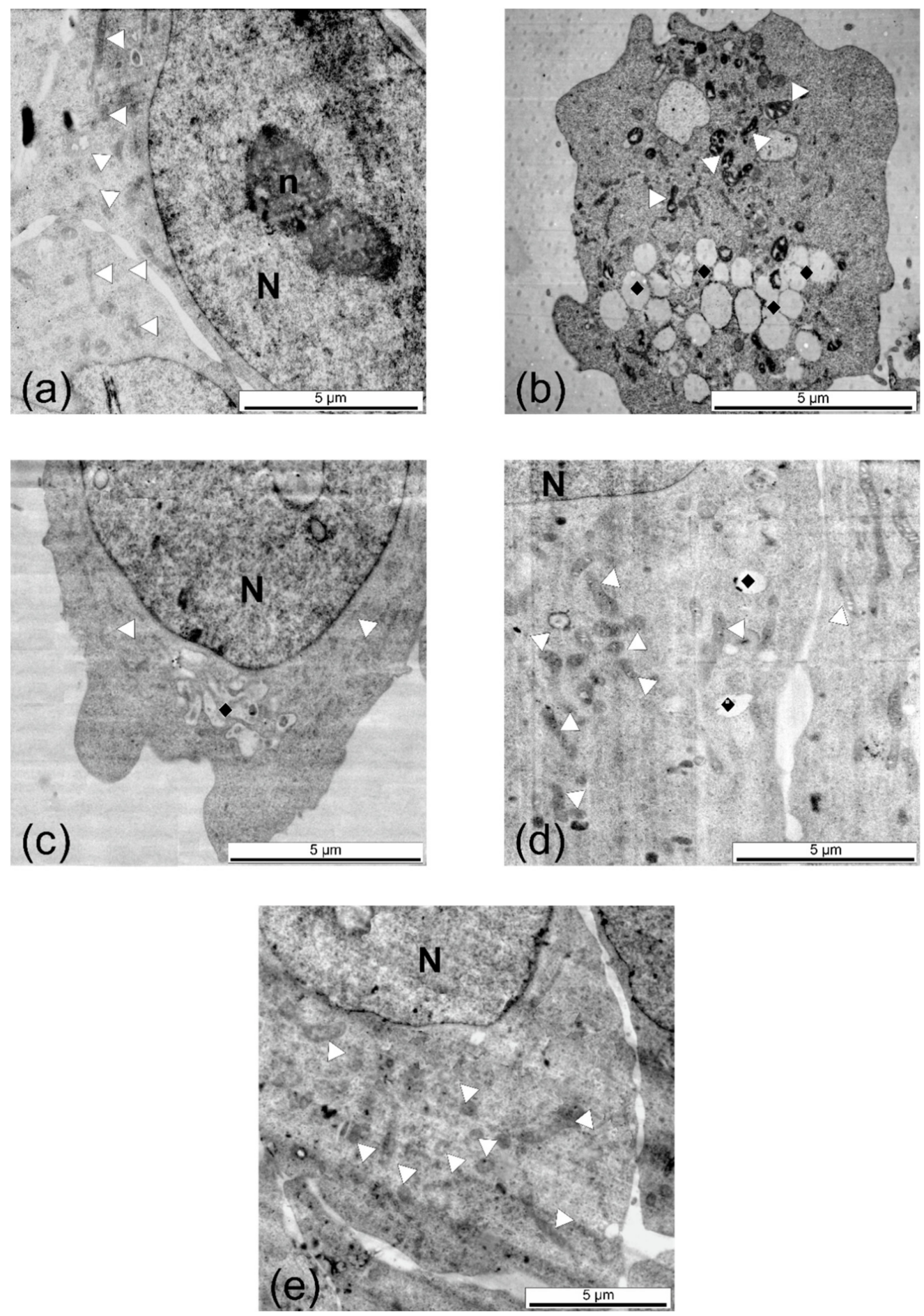

Figure 8. TEM micrographs of untreated A375 melanoma cells (a) and compared to the cells treated with (b) V. minor, (c) V. major, (d) V. major var. variegata, and (e) V. herbacea leaf extracts at $\mathrm{IC}_{50}$ values. White triangle $=$ mitochondria, black rhombs $=$ vesicles $/$ lysosomes, $\mathrm{N}=$ nucleus, $\mathrm{n}=$ nucleolus .

\section{Discussion}

Hydroalcoholic extracts were obtained from the leaves of Vinca species, which are known as medicinal plants and having a high content of alkaloids, flavonoids, and phenolic compounds, and well-documented antibacterial, antioxidant, and cytotoxic effects [46-48]. The chemical composition of plant extracts is dependent on the plant species, organ and tissue used, harvesting period, environmental conditions, extraction method, and solvent 
used for preparation $[33,49,50]$. Therefore, the leaves of Vinca species are preferred for extract preparation due to the highest alkaloid content stored in a short period [20,51]. For example, in Catharanthus roseus one of the well-known plant of the Apocynaceae family, some of the biosynthetic genes of vinblastine are expressed in epidermal cells of the leaves of the plant [52]. Moreover, since the crude extracts of the species considered herein are an important source of phytoconstituents, the TAC, TPC, and TFC were determined for all four extracts (Tables 1 and 2).

One objective was to determine the total alkaloid content by a fast and reliable assay, preferably using a relatively cheap and accessible experimental setup. A well-known colorimetric method is Dragendorff assay. This relies on the following principle: In acidic environment, $\mathrm{Bi}^{3+}$ forms a complex anion with $\mathrm{I}^{-},\left[\mathrm{BiI}_{4}\right]^{-}$, which in turn, can interact with the positive charge on the nitrogen-containing alkaloids, resulting in a fine orange precipitate. Unfortunately, not all alkaloids display a quaternary nitrogen atom at regular $\mathrm{pH}$, being the case of indole alkaloids. These representatives contain only a tertiary nitrogen atom, without charge, making their detection by Dragendorff reagent very difficult. Still, as shown here, if the optimum quantity of acid is added, the indole alkaloids can be protonated, thus, precipitating in the presence of the $\left[\mathrm{BiI}_{4}\right]^{-}$.

The Vinca extracts analyzed by HPLC have terpene indole alkaloids. This implies that the plant species share the metabolic pathways of biosynthesis from tryptophan and secologanin precursors [30,52]. This could indicate that the structure of the unidentified terpene indole alkaloids is very similar to that of vincamine, explaining the reason why all extracts, except for $V$. herbacea, had traces of it $[21,32,53]$. V. minor had the highest amount of vincamine $(65 \mu \mathrm{g} / \mathrm{g})$ and compared to other studies that reported a content of $0.057 \%$ [33] or $78.9 \mathrm{ng} / \mathrm{g}$ [54]. The method used, herein, was proved very efficient for alkaloid extraction.

According to the PCA results, there are many other alkaloids present in the studied extracts, some of them possibly being indole type as well. However, the relatively low concentration of alkaloids is not surprising. Their synthesis is strictly regulated, as they can have detrimental effects on the plant itself. Besides the alkaloids, three other main phytoconstituents classes are present: Flavonoids, hydroxybenzoic and hydroxycinnamic acids, which are known to be involved in plant protection against various abiotic or biotic forms of stress [55].

All four Vinca extracts exhibited remarkably high levels of chlorogenic acid, a natural compound synthesized via the phenylpropanoid pathway from phenylalanine, under various forms of stress [56]. This result can partly be explained by the interplay identified between chlorogenic acids and alkaloids in other plants, especially when a biotic stress is applied. For example, interesting relationships were described between chlorogenic acids and pyrrolizidine alkaloids: Depending on the bioavailable form of the alkaloid, there can be synergistic (if the alkaloid is an oxide) or antagonistic effects manifested [57]. Other natural compounds were identified, such as rutin, quercetin, and caffeic acid. Moreover, HPLC revealed additional unidentified peaks that were attributed to unknown, possibly new, compounds belonging to these classes.

Phytoconstituents in Vinca extracts are species-dependent and have synergistic action. They are responsible for the antioxidant activity (Table 2), antibacterial (Figure 4) and cytotoxic effects (Figure 5), which were highly correlated. The results showed that $V$. herbacea extract had the highest antioxidant activity, followed by $V$. major var. variegata, whereas the lowest one was attributed to $V$. major. The antioxidant potential of plant extracts is determined by different phytoconstituents, such as vincamine [58], chlorogenic acid [42], and other phenolics [59]. These findings confirm that the antioxidant potential is different for V. minor [60], V. herbacea [61], and V. major [16].

The antibacterial activity was species- and dose-dependent. V. minor had the best inhibitory effect against both $S$. aureus and E. coli, which is most probably generated by the phytoconstituents. Similar results were obtained with $V$. minor extracts against Grampositive bacteria and a lower inhibitory capacity against the Gram-negative ones [60]. 
These inhibitory effects are determined by the antibacterial compounds present, such as vincamine [62] and common plant flavonoids such as rutin, chlorogenic acid, caffeic acids, isoquercitrin, quercitrin, quercetin, etc. [63], that act synergistically. Another report proved that vincamine is effective against E. coli and S. aureus [62], and that the flavonoids rutin, chlorogenic acid, quercetin, or kaempferol were generally more effective against $E$. coli and Pseudomonas aeruginosa (Gram-negative), than against Enterococcus fecalis and S. aureus (Gram-positive) [63]. The V. herbacea extract had a proliferative effect on E. coli and an inhibitory effect on S. aureus. Also, this extract contained elevated levels of rutin, a compound with good antibacterial potential [8]. Different antibacterial effects are mentioned for rutin, with a greater inhibitory activity determined against $S$. aureus compared to E. coli [64], but also against Aeromonas hydrophyla [5]. This also applies to V. major and V. major var. variegata, even if they had weaker inhibitory potential against the tested bacterial strains. However, the potential for these extracts is still to be uncovered in further analyses, where higher doses or even their combinations could be tested.

The morphological alterations, generated by the plant extracts on the bacterial cells, were also assessed through SEM for a better understanding of the occurring processes. The E. coli bacilli were not affected significantly compared to the untreated control (Supplementary Figure S6). However, a proliferation of the extracellular matrix (glycocalyx and flagella) was observed on the samples treated with $V$. major var. variegata and $V$. herbacea and this could explain the proliferative effect observed in the microdilution method $[65,66]$. The $S$. aureus cocci were found in different stages of degradation when treated with the Vinca extracts (Figure 5), and the ones treated with V. herbacea showed signs of membrane disruption, similar to other findings [67]. Still, the mode of action of phenols and alkaloids against bacteria is yet to be elucidated, so that the base for new and alternative antibiotics could be settled [1].

The Vinca extracts had rather proliferative effects on $\mathrm{HaCaT}$ cells at concentrations between $0.09-2 \%$, and inhibitory effects for the $3 \%$ concentration used. The obtained results could be explained by a dose-dependent cytotoxic effect on the cell lines [68]. The melanoma cells (A375) were negatively affected by all extracts in a dose-dependent manner as well, but $V$. herbacea and $V$. major var. variegata showed also a promising anticancer activity. The mechanism of action of Vinca alkaloids (vinblastine and vincristine) [69] is by interaction with $\beta$-tubulin at a region adjacent to the GDP-binding site, at the plus end of microtubules, known as the 'vinca domain'. These have different modes of actions (inhibition or acceleration of cell division), depending on the concentration [70]. Consequently, the vinca domain could bind other Vinca alkaloids, only this time the effects could be the opposite of apoptosis as we observed. However, to our knowledge, there is no literature available to confirm or infirm this theory.

Additionally, the ultrastructural changes induced by the Vinca extracts on the human cell lines, were assessed thorough TEM. As expected, the HaCaT cells which expressed high viability also had a high number of mitochondria, compared to untreated controls (Supplementary Figure S9), and this could be due to the phenolic content present in the plant extracts [71]. On the other hand, the A375 cells were most affected by the V. minor extract as indicated by the ultrastructural analysis (Figure 8), where multiple lysosomes were detected. This is a clear sign of necrosis, a premature death of the cells caused by the extract [72], and similar results were previously reported [73].

Henceforth, more complex analyses are required to determine the mode of action against pathogens and the anticancer potential of Vinca alkaloids, while the synergistic action of Vinca extracts will be exploited in a future research.

\section{Materials and Methods}

\subsection{Plant Material and Extract Preparation}

Vinca minor L. (lesser periwinkle), Vinca major L. (great periwinkle), Vinca major L. var. variegata 'Louden', and $V$. herbacea Waldst. and Kit. (herbaceous periwinkle) were collected from 'Alexandru Borza' Botanical Garden of Cluj-Napoca, Romania, and identified by 
Pârvu Marcel. A voucher specimen for each species was deposited in the Herbarium of 'Babeş-Bolyai' University, Cluj-Napoca, Romania (V. minor CL 665977, V. major CL 668019, V. major var. variegata CL 668018, V. herbacea CL 668021).

During the flowering season (April-May and September), the fully developed leaves of adult plants were collected and thoroughly washed with tap and distilled water, cut into small fragments $(0.5-1 \mathrm{~cm})$, weighed, and placed in the percolator. The extraction of phytoconstituents was conducted as previously described [9], through the cold repercolation method in a 1:2 (w:v) solvent to fresh herba ratio. For three days the fresh herba was extracted with $70 \%$ ethanol (Merck, Bucharest, Romania), at room temperature. The fluid extracts obtained by filtration were as follows (w:v/g:mL): 1:1.2 (V. minor), 1:1.4 (V. major), 1:1.5 ( $V$. major var. variegata), and 1:2 (V. herbacea). The final ethanol concentration was 30\% in all obtained extracts.

\subsection{Phytochemical Analyses of the Vinca Leaf Extracts \\ 4.2.1. HPLC-DAD Method}

All reagents were of analytical grade purity and unless otherwise specified. All reagents were acquired from Sigma-Aldrich (Merck, Bucharest, Romania).

The chromatographic separations and detection were performed as previously described [74], on an Agilent 1200 HPLC system (Agilent Technologies Inc., Waldbronn, Germany) equipped with a vacuum degasser and temperature-controlled sample tray. A quaternary pump controlled the mobile phase flow, and the samples were automatically injected. The chromatographic separations were run on a Zorbax SB-C18 column $(250 \mathrm{~mm} \times 4.6 \mathrm{~mm}, 5 \mu \mathrm{m}$ particle size) from Agilent (Agilent Technologies Inc., Santa Clara, CA, USA), placed in a column thermostat compartment, and the detection was accomplished via a DAD detector. The injection volume was $8 \mu \mathrm{L}(0.22 \mu \mathrm{m}$ filtered extract), the column temperature was set to $30^{\circ} \mathrm{C}$, and the flow rate was $1 \mathrm{~mL} / \mathrm{min}$.

The finally employed optimum method consisted of a multistep gradient elution system using $0.1 \%$ trifluoroacetic acid in ultrapure water as solvent $\mathrm{A}$ and acetonitrile as solvent $B$. The steps of the gradient were as follows: $0-2 \mathrm{~min}$ isocratic at $8 \% \mathrm{~B}, 2-17 \mathrm{~min}$ from 8 to $30 \% \mathrm{~B}, 17-27 \mathrm{~min}$ isocratic at $30 \% \mathrm{~B}, 27-37 \mathrm{~min}$ from $30 \%$ to $85 \% \mathrm{~B}, 37-40 \mathrm{~min}$ from $85 \%$ to $95 \% \mathrm{~B}, 40-41 \mathrm{~min}$ isocratic at $95 \% \mathrm{~B}$, and $41-41.1 \mathrm{~min}$ back to $8 \% \mathrm{~B}$, where was kept until min 44. The UV-Vis detection of the compounds was performed using the DAD detector that measured the entire spectrum in $210-600 \mathrm{~nm}$ region $(2 \mathrm{~nm}$ resolution), every $2 \mathrm{~s}$; the chromatograms were monitored at 242, 260, 280,320, and $340 \mathrm{~nm}$. The standards used were: 3,4-dihydroxybenzoic acid, chlorogenic acid, 4-hydroxybenzoic acid, caffeic acid, syringic acid, rutin, $p$-coumaric acid, isoquercitrin, ferulic acid, quercitrin, myricetin, berbamine, vincamine, jatrorrhizine, quercetin, palmatine, berberine, kaempferol, vinblastine, and galangin. Calibration curve was constructed using a mixture of the above-mentioned standards at $35,53,70,105,140,210,280 \mu \mathrm{g} / \mathrm{mL}$, and the area of the peak by integration employed by the Agilent soft. Identification of the compounds from the analyzed samples was done using both chromatographic retention time and UV-Vis spectral similarities that were done by the built-in soft with the spectra of the analytical standards. The chemometric investigations of the spectral features of chromatographic peaks that contribute to at least $1 \%$ of the total peak area at $230 \mathrm{~nm}$, were done as previously described [75]; before performing PCA analysis, all chromatograms were normalized by min-max method.

\subsubsection{Alkaloid Content}

The total alkaloid content (TAC) was determined by an adapted Dragendorff assay [76]. The first solution consisted of $43.8 \mathrm{mM} \mathrm{Bi}\left(\mathrm{NO}_{3}\right)_{3}$ and $1.66 \mathrm{M}$ tartaric acid, in $20 \%$ acetic acid (aqueous solution). A second solution was obtained by dissolving $\mathrm{KI}$ in ultrapure water to a final concentration of $2.4 \mathrm{M}$. Both solutions were shaken vigorously until homogenization. Afterwards, $5 \mathrm{~mL}$ of the first solution were mixed with $2 \mathrm{~mL}$ of the second solution. Next, $260 \mu \mathrm{L}$ of this reagent were mixed thoroughly with $30 \mu \mathrm{L}$ of $100 \mu \mathrm{g} / \mathrm{mL}$ of each extract, and $10 \mu \mathrm{L}$ of glacial acetic acid. The optical density was registered using a Tecan 
multiplate reader (Tecan Trading AG, Mannedorf, Switzerland) at $560 \mathrm{~nm}$. The standard used for the calibration curve was vinblastine (concentration range: 1 to $20 \mu \mathrm{g} / \mathrm{mL}$ ) and all measurements were performed in duplicate.

\subsubsection{Colorimetric Determination of Phytoconstituents in the Vinca Leaf Extracts}

For the determination assays of all phytoconstituent classes, the extracts were diluted to a concentration of $100 \mathrm{mg} / \mathrm{mL}$ in $30 \%$ ethanol solution. The total phenolic content (TPC) was determined by Folin-Ciocâlteu reducing capacity assay [77]: $25 \mu \mathrm{L}$ of each extract were mixed with $25 \mu \mathrm{L}$ of Folin-Ciocâlteu reagent and $200 \mu \mathrm{L}$ of ultrapure water, and incubated for $5 \mathrm{~min}$. Then, $25 \mu \mathrm{L}$ of $\mathrm{Na}_{2} \mathrm{CO}_{3}$ solution (stock concentration: $10.6 \mathrm{~g} / 100 \mathrm{~mL}$ ) were added and the resulting mixture was further incubated for $60 \mathrm{~min}$ in the dark. The absorbance was measured at $725 \mathrm{~nm}$ before, and after, the $60 \mathrm{~min}$ incubation period. The corresponding percentages were calculated as described in the literature. The standard used for the calibration curve was gallic acid (in $2-40 \mu \mathrm{g} / \mathrm{mL}$ range).

The total flavonoid content (TFC) was determined by $\mathrm{AlCl}_{3}$ complexation (procedure 1) [78]. Thus, $10 \mu \mathrm{L}$ of each extract were mixed with $50 \mu \mathrm{L}$ of $2 \% \mathrm{AlCl} 3$ solution and $50 \mu \mathrm{L}$ of $1 \mathrm{M}$ sodium acetate in $140 \mu \mathrm{L}$ ultrapure water, in a 96-well plate. After an incubation period of about $5 \mathrm{~min}, 50 \mu \mathrm{L}$ of $0.1 \mathrm{mM} \mathrm{HCl}$ were added under vigorous shaking. After an additional $20 \mathrm{~min}$, the absorbance was measured at $452 \mathrm{~nm}$ using a Tecan Spark multiplate reader. The standard used for the calibration curve was rutin (in 1.6-50 $\mu \mathrm{g} / \mathrm{mL}$ range). All the above assays were performed in duplicates.

\subsection{In Vitro Antioxidant Activity}

All reagents were of analytical grade purity, and unless specified otherwise, all reagents were acquired from Sigma-Aldrich (Merck, Bucharest, Romania).

For the antioxidant capacity assays performed, the extracts were diluted to a concentration of $100 \mathrm{mg} / \mathrm{mL}$ in 30\% ethanol solution. Rutin Equivalent Antioxidant Capacity (REAC), in fact ABTS bleaching assay with rutin as standard [79] and cupric ion reducing antioxidant capacity (CUPRAC) [79] are presented in the Supplementary Material.

Induced peroxidation of liposomes (LipPx) assay was performed as follows: Liposomes of $0.2 \mathrm{mg} / \mathrm{mL}$ concentration in phosphate buffer saline (PBS) of $7.4 \mathrm{pH}$ were sonicated for $30 \mathrm{~min}$ until homogenization [80]. Further, $290 \mu \mathrm{L}$ of this solution was mixed with $10 \mu \mathrm{L}$ of each extract $(10 \mu \mathrm{g} / \mathrm{mL})$ and the reaction was triggered by the addition of cytochrome $\mathrm{C}$, to a final concentration of $2 \mu \mathrm{M}$. The reaction evolution was recorded at $235 \mathrm{~nm}$ using the Tecan Spark multiplate reader overnight, at $25^{\circ} \mathrm{C}$. The corresponding lag phase was determined as the value of inflexion point for all kinetic measurements. Rutin (in $0.067-2.3 \mu \mathrm{g} / \mathrm{mL}$ range) was used as a standard to obtain the kinetic curve.

\subsection{Antibacterial Activities}

The antibacterial activity of the plant extracts was tested on a Gram-positive model, Staphylococcus aureus (ATCC: 25923) and a Gram-negative model, E. coli (ATCC: 25922), using the agar-well diffusion and microdilution methods adapted after Carpa, et al. [81]. The bacterial strains were incubated at $37^{\circ} \mathrm{C}$, for $24 \mathrm{~h}$, in Petri dishes with Mueller-Hinton (MH) agar media (VWR Chemicals, VWR International, Darmstadt, Germany), and were further adjusted to a $0.5 \mathrm{McFarland}$ turbidity standard, according to EUCAST protocols [82].

\subsubsection{Agar-Well Diffusion Method}

For the agar-well diffusion method Petri dishes with $\mathrm{MH}$-agar media were inoculated with each bacterial strain and left at room temperature for $30 \mathrm{~min}$ to infiltrate. Subsequently, $6 \mathrm{~mm}$ diameter wells were carved in the agar using a cut sterile pipette tip. The wells were then filled with sterile cotton beads. Each bead was loaded with $150 \mu \mathrm{L}$ of each extract. The plate also contained a vehicle control with $30 \%$ ethanol and a positive control with ciprofloxacin (CIP, $5 \mu \mathrm{g} / \mathrm{mL}$ concentration). After $24 \mathrm{~h}$ incubation at $37^{\circ} \mathrm{C}$, the formed 
hallow around the wells was measured. Each experiment was conducted six times and the mean was calculated.

\subsubsection{Microdilution Method}

For the microdilution method, 96-well plates were prepared as following: $100 \mu \mathrm{L}$ $\mathrm{MH}$-broth media in each well and $100 \mu \mathrm{L}$ of each extract was inoculated (in the first row only), and two-fold serial dilutions were performed, with concentrations ranging from $50 \%$ to $0.09 \%$. All wells were then filled with $10 \mu \mathrm{L}$ of bacterial suspensions, with final concentrations of $5 \times 10^{5} \mathrm{CFU} / \mathrm{mL}$ (colony forming units). Each plate had an untreated control and a positive control with $4.5 \%$ CIP. Vehicle controls with ethanol and media with extracts were also prepared in separate plates. The plates were incubated for $24 \mathrm{~h}$ at $37^{\circ} \mathrm{C}$ and the absorbance was read at $600 \mathrm{~nm}$, using the BioTech Epoch plate reader (BioTek Instruments, Winooski, VT, USA) and Gen5 Software (version 1.09).

Bacterial inhibition was expressed as inhibition percentages and calculated according to Equation (1):

$$
\text { Inhibition }(\%)=\frac{\text { registered absorbance }(\mathrm{nm})}{\text { untreated control }(\mathrm{nm})} 100
$$

\subsubsection{Morphological Examination through Scanning Electron Microscopy}

Scanning electron microscopy (SEM) was used to assess the possible morphological damages induced on the bacterial strains. The method was adapted after an existing protocol [83] and modified as follows; the fixator solution consisted of $0.5 \%$ alcian blue, $2 \%$ glutaraldehyde, and 2\% paraformaldehyde in 0.15 M PBS (Merck, Bucharest, Romania); the bacteria were incubated for $7 \mathrm{~h}$ at $4{ }^{\circ} \mathrm{C}$; dehydration occurred in acetone in different concentrations $(30 \%, 50 \%, 70 \%, 80 \%, 90 \%$, and $100 \%)$, for $10 \mathrm{~min}$ each step, at $4{ }^{\circ} \mathrm{C}$. Additionally, the samples were post-fixed with hexamethyldisilazane (1:1 with acetone, and 1:0, $10 \mathrm{~min}$ ). The samples were examined with SEM Hitachi SU8230 (Hitachi, Tokyo, Japan).

\subsection{In Vitro Cytotoxicity Assays \\ 4.5.1. Biochemical Assays}

Cytotoxicity assays were conducted on normal human keratinocytes (HaCaT 300493, CLS, Heidelberg, Germany) and skin melanoma (A375, ATCC CRL-1619), as previously described [84]. Briefly, the cells were cultured on $25 \mathrm{~cm}^{2}$ plastic dishes in Dulbecco's Modified Eagle's media (DMEM) with $4.5 \mathrm{~g} / \mathrm{L}$ glucose (Lonza Group Ltd., Basel, Switzerland), supplemented with 10\% fetal calf serum (FCS; Ghibco, Thermo Fisher Scientific, Paisley, UK), $1 \%$ penicillin-streptomycin and 1\% L-glutamine (Lonza Group Ltd., Basel, Switzerland). The plates were kept in a humidified incubator at $37{ }^{\circ} \mathrm{C}$ with $5 \% \mathrm{CO}_{2}$ atmosphere. At $80 \%$ confluence, the cells were harvested using $0.25 \%$ trypsin-EDTA (Lonza Group Ltd., Basel, Switzerland) and sub-cultured in 96-well plates.

Aliquots of $100 \mu \mathrm{L}$ of the prepared cells were plated in each well, at a density of $12 \times 10^{3}$ cells/well (HaCaT) and $10^{4}$ cells/well (A375) and were left to attach for $24 \mathrm{~h}$. After incubation, the culture media was replaced with media containing plant extracts in final concentrations ranging from $0.09 \%$ to $3 \%$, and each plate had untreated, negative, and positive controls, depending on the assay (cells with $2 \%$ Tween 20 solution and lipopolysaccharides). Based on preliminary investigations and on the consulted literature, the HaCaT cells were left with the plant extracts for $48 \mathrm{~h}$ and the A375 cells, for $72 \mathrm{~h}$. The viability was analyzed through MTT assay, membrane integrity was evaluated based on the LDH assay, and signs of oxidative stress were determined through the NO assay. The detailed protocols are presented in the Supplementary Material.

Additionally, the median inhibitory concentration $\left(\mathrm{IC}_{50}\right)$ was calculated according to Equation (2):

$$
\mathrm{x}=\frac{\mathrm{y}-\mathrm{c}}{\mathrm{m}}
$$


where $\mathrm{x}$ is the median concentration, $\mathrm{y}$ is $50 \%, \mathrm{~m}$ is the coefficient calculated from the exponential fit of the data, and $\mathrm{c}$ is a constant generated by the exponential fitting of the data.

\subsubsection{Ultrastructural Investigation through Transmission Electron Microscopy}

The ultrastructural modifications were investigated through transmission electron microscopy (TEM). The samples were prepared as previously described [44] and adapted after Hayat [85]. The detailed protocol is presented in the Supplementary Material. The samples were examined using TEM Jeol JEM 1010 (Jeol, Tokyo, Japan) and SEM Hitachi SU8230.

\subsection{Statistical Analyses}

Each phytochemical analysis and antioxidant activity was performed in duplicate, and the mean and standard deviation were then calculated. In the biological analyses, each of the concentrations for the cytotoxic and antibacterial activities was tested six times, and all data refer to the mean \pm standard error of at least four independent experiments. The statistical analyses performed were: Principal Component Analysis (performed in STATISTICA 12), Pearson's correlation coefficient $(r)$, Spearman's rank correlation coefficient $(\rho)$, Student's t-test, and one-way ANOVA statistical analyses performed using Origin 8 software (Origin Lab Corporation, Northampton, MA, USA). Values of $p \leq 0.05$ were considered statistically significant.

\section{Conclusions}

The chemical composition of Vinca minor, V. major, V. major var. variegata, and $V$. herbacea is correlated with the observed pharmacological activities, such as antioxidant, antibacterial, and cytotoxic potentials, which brings novelty to the field. The total alkaloid content was determined for the first time in these hydroalcoholic extracts, revealing that $V$. minor was the richest in alkaloids and that traces of vincamine are present in $V$. major and $V$. major var. variegata. Surprisingly, $V$. herbacea had a remarkably high rutin content. Based on this complex chemical composition, the antioxidant activity, antibacterial potential, and cytotoxic effects were species- and dose-dependent. The high antioxidant potential of $V$. herbacea could be related to the high amount of rutin, and because $V$. minor had the highest alkaloid content, the antibacterial effects were greater for this extract. Of course, the generated effects were due to the synergistic action of the plethora of phytoconstituents, and this was also reflected in the cytotoxic activity against HaCaT and A375 cellular lines. Under the current circumstances, all tested plants kept their pharmacological potential. Moreover, $V$. herbacea and $V$. major var. variegata acted similar to $V$. minor. The chemical profile of the Vinca plant extracts, together with the observed effects in the treated cells, holds valuable information for the development of new alternative treatments. Still, the mode of action of distinctly detected compounds must be characterized, and unknown compounds are yet to be identified.

Supplementary Materials: The following are available online, Detailed Supplementary Methods, Figure S1: DAD UV-Vis molecular absorption spectra of representative compounds in the analyzed plant species extracts after chromatographic separation: (A) Vinca minor (Vm), (B) Vinca herbacea (Vh), (C) Vinca major (VM), (D) Vinca major var. variegata (VMv). Figure S2: Calibration curves for rutin (TFC) and gallic acid (TPC). Figure S3: Graphical distribution of antibacterial activity assessed through agar well diffusion method. The values represent the mean of six individual experiments \pm standard error of the mean; CIP = ciprofloxacin, $\mathrm{EtOH}=$ ethanol; Student's $\mathrm{t}$ test was performed to determine if the Gram-positive strain, S. aureus, is affected differently from the Gram-negative strain, E. coli; ${ }^{* * *} p<0.0001$. Figure S4: The total flavonoid (A) and phenolic (B) content of the analyzed extracts is represented in relation to the ranked effects of the extracts against E. coli; The total alkaloid (C) and phenolic (D) content represented in relation to the ranked effects of the extracts against Staphylococcus aureus. Figure S5. SEM micrographs of E. coli cells treated with Vinca leaf extracts at Minimal Inhibitory Concentration (MIC) values. (A) untreated control, treated with (B) V. minor, (C) V. major, (D) V. major var. variegata, (E) V. herbacea. Figure S6. The 
total flavonoid (A) and phenol (B) content of the analyzed extracts represented in relation to the $\mathrm{IC}_{50}$ values observed against the HaCaT cells. The total flavonoid (C) and phenol (D) content of the analyzed extracts represented in relation to the $\mathrm{IC}_{50}$ values observed against the A375 cells. Figure S7. LDH release expressed in relation to the total alkaloid content in HaCaT cells (A) and A375 cells (B). The LDH release expressed in relation to the total phenolic content in A375 cells (C). NO concentration expressed in relation to the total phenolic content (D) and total alkaloid content (E) in HaCaT cells. NO concentration expressed in relation to the total alkaloid content in A375 cells (F). Figure S8. TEM micrographs of the HaCaT keratinocytes treated with Vinca extracts. (A-B) untreated control, treated with (C) V. minor, (D) V. major, (E) V. major var. variegata, and (F) V. herbacea. White triangles $=$ mitochondria, black rhombs $=$ vesicles, $\mathrm{N}=$ nucleus, $\mathrm{n}=$ nucleolus. Table $\mathrm{S} 1$. Retention time, spectral features, phytochemical group, and chromatographic area (at $230 \mathrm{~nm}$ ) for the peaks that were chemometrically analyzed. Phytochemical group (Gr.) was attributed after PCA analysis based on spectral similarities. Standards were also included.

Author Contributions: Conceptualization, M.P. and A.C.; methodology, A.C., C.Z.-T., A.C.M. and R.C.; software, A.C. and A.C.M.; validation, M.P., A.C.M. and R.C.; formal analysis, M.P.; investigation, A.C.; resources, M.P. and A.C.; data curation, A.C.; writing-original draft preparation, A.C.; writing-review and editing, M.P.; visualization, C.Z.-T., A.C.M. and R.C.; supervision, M.P.; project administration, M.P. and A.C.; funding acquisition, M.P., A.C., A.C.M. and C.Z.-T. All authors have read and agreed to the published version of the manuscript.

Funding: The present work has received financial support through the project Entrepreneurship for innovation through doctoral and postdoctoral research POCU/360/6/13/123886 co-financed by the European Social Fund, through the Operational Program for Human Capital 2014-2020 and by the 2020 Development Fund of the 'Babes-Bolyai' University. This work was also partly supported by a grant of the Ministry of Research, Innovation and Digitization, CNCS/CCCDI-UEFISCDI, project number TE-2019-1396, within PNCDI III.

Institutional Review Board Statement: Not applicable.

Informed Consent Statement: Not applicable.

Data Availability Statement: Samples of the data are provided by the corresponding author on request.

Acknowledgments: We would like to thank Dorina Podar and Lorena Vacar for proofreading the paper.

Conflicts of Interest: The authors declare no conflict of interest.

Sample Availability: Samples of the compounds are available from the authors.

\section{References}

1. Jhanji, R.; Bhati, V.; Singh, A.; Kumar, A. Phytomolecules against bacterial biofilm and efflux pump: An in silico and in vitro study. J. Biomol. Struct. Dyn. 2019. [CrossRef]

2. Siegel, R.L.; Miller, K.D.; Jemal, A. Cancer Statistics, 2019. CA Cancer J. Clin. 2019, 69, 7-34. [CrossRef] [PubMed]

3. D'Costa, V.M.; King, C.E.; Kalan, L.; Morar, M.; Sung, W.W.L.; Schwarz, C.; Froese, D.; Zazula, G.; Calmels, F.; Debruyne, R.; et al. Antibiotic resistance is ancient. Nature 2011, 477, 457-461. [CrossRef] [PubMed]

4. AlSalhi, M.S.; Elangovan, K.; Ranjitsingh, A.J.A.; Murali, P.; Devanesan, S. Synthesis of silver nanoparticles using plant derived 4- $\mathrm{N}$-methyl benzoic acid and evaluation of antimicrobial, antioxidant and antitumor activity. Saudi J. Biol. Sci. 2019, 26, 970-978. [CrossRef] [PubMed]

5. Deepika, M.S.; Thangam, R.; Vijayakumar, T.S.; Sasirekha, R.; Vimala, R.T.V.; Sivasubramanian, S.; Arun, S.; Babu, M.D.; Thirumurugan, R. Antibacterial synergy between rutin and florfenicol enhances therapeutic spectrum against drug resistant Aeromonas hydrophila. Microb. Pathogen. 2019, 135. [CrossRef] [PubMed]

6. Shukla, S.; Mehta, A. Anticancer potential of medicinal plants and their phytochemicals: A review. Braz. J. Bot. 2015, 38, 199-210. [CrossRef]

7. Chagas, C.M.; Alisaraie, L. Metabolites of Vinca alkaloid vinblastine: Tubulin binding and activation of nausea-associated receptors. ACS Omega 2019, 4, 9784-9799. [CrossRef] [PubMed]

8. Ganeshpurkar, A.; Saluja, A.K. The pharmacological potential of rutin. Saudi Pharm. J. 2017, 25, 149-164. [CrossRef]

9. Pârvu, M.; Vlase, L.; Fodorpataki, L.; Pârvu, O.; Bartha, C.; Roșca-Casian, O.; Barbu-Tudoran, L.; Pârvu, A.E. Chemical composition of celandine (Chelidonium majus L.) extract and its effects on Botrytis tulipae (Lib.) lind fungus and the tulip. Not. Bot. Hort. Agrobot. 2013, 41, 414-426. [CrossRef] 
10. Meira, C.S.; Guimarães, E.T.; dos Santos, J.A.F.; Moreira, D.R.M.; Nogueira, R.C.; Tomassini, T.C.B.; Ribeiro, I.M.; de Souza, C.V.C.; dos Santos, R.R.; Soares, M.B.P. In vitro and in vivo antiparasitic activity of Physalis angulata L. concentrated ethanolic extract against Trypanosoma cruzi. Phytomedicine 2015, 22, 969-974. [CrossRef] [PubMed]

11. Mirzaei, H.; Naseri, G.; Rezaee, R.; Mohammadi, M.; Banikazemi, Z.; Mirzaei, H.R.; Salehi, H.; Peyvandi, M.; Pawelek, J.M.; Sahebkar, A. Curcumin: A new candidate for melanoma therapy? Int. J. Can. 2016, 139, 1683-1695. [CrossRef] [PubMed]

12. PLANTS. United States Department of Agriculture. PLANTS Database. Available online: https://plants.sc.egov.usda.gov (accessed on 14 May 2021).

13. EEA. European Environment Agency. Available online: https:/ / eunis.eea.europa.eu (accessed on 14 May 2021).

14. Koyuncu, M. A new species of Vinca (Apocynaceae) from eastern Anatolia, Turkey. Turk. J. Bot. 2012, 36, 247-251. [CrossRef]

15. POW. Plants of the World Online. Available online: http://powo.science.kew.org/ (accessed on 14 May 2021).

16. Cheng, G.-G.; Zhao, H.-Y.; Liu, L.; Zhao, Y.-L.; Song, C.-W.; Gu, J.; Sun, W.-B.; Liu, Y.-P.; Luo, X.-D. Non-alkaloid constituents of Vinca major. Chin. J. Nat. Med. 2016, 14, 56-60. [CrossRef] [PubMed]

17. Sukhdev, S.; Shamsher, K.S.; Indu, K. Antilipase activity guided fractionation of Vinca major. J. King Saud Univ. Sci. 2017. [CrossRef]

18. Abouzeid, S.; Hijazin, T.; Lewerenz, L.; Hansch, R.; Selmar, D. The genuine localization of indole alkaloids in Vinca minor and Catharanthus roseus. Phytochemistry 2019, 168, 112110. [CrossRef] [PubMed]

19. Boga, M.; Kolak, U.; Topcu, G.; Bahadori, F.; Kartal, M.; Farnsworth, N.R. Two new indole alkaloids from Vinca herbacea L. Phytochem. Lett. 2011, 4, 399-403. [CrossRef]

20. Boyadzhiev, L.; Yordanov, B. Pertraction of indole alkaloids from Vinca minor L. Sep. Sci. Technol. 2004, 39, 1321-1329. [CrossRef]

21. Liu, J.; Liu, Y.; Pan, Y.-j.; Zu, Y.-G.; Tang, Z.-H. Determination of alkaloids in Catharanthus roseus and Vinca minor by highperformance liquid chromatography-tandem mass spectrometry. Anal. Lett. 2015. [CrossRef]

22. Ciorîță, A.; Tripon, S.C.; Mircea, I.G.; Podar, D.; Barbu-Tudoran, L.; Mircea, C.; Pârvu, M. The Morphological and Anatomical Traits of the Leaf in Representative Vinca Species Observed on Indoor- and Outdoor-Grown Plants. Plants 2021, 10, 622. [CrossRef] [PubMed]

23. Almagro, L.; Fernández-Pérez, F.; Pedreño, M.A. Indole alkaloids from Catharanthus roseus: Bioproduction and their effect on human health. Molecules 2015, 20, 2973-3000. [CrossRef] [PubMed]

24. Verma, P.; Sharma, A.; Khan, S.A.; Shanker, K.; Mathur, A.K. Over-expression of Catharanthus roseus tryptophan decarboxylase and strictosidine synthase in rol gene integrated transgenic cell suspensions of Vinca minor. Protoplasma 2015, 252, 373-381. [CrossRef]

25. Moudi, M.; Go, R.; Seok Yien, C.Y.; Nazre, M. Vinca alkaloids. Int. J. Prevent. Med. 2013, 41, 1231-1235.

26. Lucas, H. Ueber den Bitterstoff der Blätter von Vinca minor L. Phys. Chem. Prakt. Pharm. 1859, 147, 147-150. [CrossRef]

27. Scheindlin, S.; Rubin, N. Isolation of an alkaloid from Vinca minor. J. Am. Pharm. Assoc. 1955, 44, 330-332. [CrossRef]

28. Mokry, J.; Kompis, I.; Dubravkova, L.; Sefcovic, P. Alkaloids of Vinca minor L. The structure of vincadine and vincaminoreine. Tetrahedron Lett. 1962, 25, 1185-1188. [CrossRef]

29. Pyuskyulev, B.; Ognyanov, I.; Panov, P. Alkaloide aus Vinca herbacea W. K. II Norfluorocurarin. Tetrahedron Lett. 1967, 46, 4559-4562. [CrossRef]

30. Cheng, G.-G.; Zhao, Y.-L.; Zhang, Y.; Lunga, P.-K.; Hu, D.-B.; Li, Y.; Gu, J.; Song, C.-W.; Sun, W.-B.; Liu, Y.-P.; et al. Indole alkaloids from cultivated Vinca major. Tetrahedron 2014, 70, 8723-8729. [CrossRef]

31. Tulyaganov, T.S.N. A M Alkaloids of Vinca minor. Chem. Nat. Comp. 2000, 36, 540. [CrossRef]

32. Verma, P.; Khan, S.A.; Masood, N.; Manika, N.; Sharma, A.; Verma, N.; Luqman, S.; Mathur, A.K. Differential rubisco content and photosynthetic efficiency of rol gene integrated Vinca minor transgenic plant: Correlating factors associated with morphoanatomical changes, gene expression and alkaloid productivity. J. Plant Physiol. 2017, 219, 12-21. [CrossRef] [PubMed]

33. Farahanikia, B.; Akbarzadeh, T.; Jahangirzadeh, A.; Yassa, N.; Shams Ardekani, M.R.; Mirnezami, T.; Hadjiakhoondi, A.; Khanavi, M. Phytochemical investigation of Vinca minor cultivated in Iran. Iran. J. Pharm. Res. 2011, 10, 777-785.

34. Demessie, Z.; Woolfson, K.N.; Yu, F.; Qu, Y.; De Luca, V. The ATP binding cassette transporter, VmTPT2/VmABCG1, is involved in export of the monoterpenoid indole alkaloid, vincamine in Vinca minor leaves. Phytochemistry 2017, 140, 118-124. [CrossRef] [PubMed]

35. Koel, M.; Kuhtinskaja, M.; Vaher, M. Extraction of bioactive compounds from Catharanthus roseus and Vinca minor. Sep. Purif. Technol. 2020, 252. [CrossRef]

36. Boyadzhiev, L.; Mecheva, D.; Yordanov, B. Extraction of vincamine from Periwinkle (Vinca minor L.): Obtaining of total extract. C. R. Acad. Bulg. Sci. 2002, 55, 49-52.

37. El-Dessouki, A.M.; El Fattah, M.A.; Awad, A.S.; Zak, H.F. Zafirlukast and vincamine ameliorate tamoxifen-induced oxidative stress and inflammation: Role of the JNK/ERK pathway. Life Sci. 2018, 202, 78-88. [CrossRef]

38. Hasa, D.; Perissutti, B.; Dall'Acqua, S.; Chierotti, M.R.; Gobetto, R.; Grabnar, I.; Cepek, C.; Voinovich, D. Rationale of using Vinca minor Linne dry extract phytocomplex as a vincamine's oral bioavailability enhancer. Eur. J. Pharm. Biopharm. 2013. [CrossRef]

39. Wang, J.; Lv, X.; Xu, J.; Liu, X.; Du, T.; Sun, G.; Chen, J.; Shen, X.; Wang, J.; Hu, L. Design, synthesis and biological evaluation of vincamine derivatives as potential pancreatic B-cells protective agents for the treatment of type 2 diabetes mellitus. Eur. J. Med. Chem. 2020, 188. [CrossRef] [PubMed] 
40. Söhretoglu, D.; Masullo, M.; Piacente, S.; Kirmizibekmez, H. Iridoids, monoterpenoid glucoindole alkaloids and flavonoids from Vinca major. Biochem. Syst. Ecol. 2013, 49, 69-72. [CrossRef]

41. Roepke, J.; Salim, V.; Wu, M.; Thamm, A.M.; Murata, J.; Ploss, K.; Boland, W.; De Luca, V. Vinca drug components accumulate exclusively in leaf exudates of Madagascar periwinkle. Proc. Natl. Acad. Sci. USA 2010, 107, 15287-15292. [CrossRef] [PubMed]

42. Foddai, M.; Maldini, M.; Addis, R.; Petretto, G.L.; Chessa, M.; Pintore, G. Profiling of the bioactive compounds in flowers, leaves and roots of Vinca sardoa. Nat. Prod. Commun. 2017, 12, 933-936. [CrossRef]

43. Chen, Q.; Lu, X.; Guo, X.; Guo, Q.; Li, D. Metabolomics Characterization of Two Apocynaceae Plants, Catharanthus roseus and Vinca minor, Using GC-MS and LC-MS Methods in Combination. Molecules 2017, 22, 997. [CrossRef]

44. Macavei, S.G.; Suciu, M.; Craciunescu, I.; Barbu-Tudoran, L.; Tripon, S.C.; Balan, R. Hyperthermia effects on normal and tumor skin cells. Ann. RSCB 2016, 21, 11-21.

45. Bryan, N.S.; Grisham, M.B. Methods to detect nitric oxide and its metabolites in biological samples. Free Radic. Biol. Med. 2007, 43, 645-657. [CrossRef] [PubMed]

46. Islam, B.; Lustberg, M.; Staff, N.P.; Kolb, N.; Alberti, P.; Argyriou, A.A. Vinca alkaloids, thalidomide and eribulin-induced peripheral neurotoxicity: From pathogenesis to treatment. J. Peripher. Nerv. Soc. 2019, 24 (Suppl. 2), S63-S73. [CrossRef]

47. Liao, F.-Y.; Xie, Y.; Jiang, H. The effect of water stress on the physiology of Vinca major 'variegata'. Appl. Mech. Mater. 2013, 409-410, 782-787. [CrossRef]

48. Jaleel, A.C.; Gopi, R.; Manivannan, P.; Gomathinayagam, M.; Sridharan, R.; Panneerselvam, R. Antioxidant potential and indole alkaloid profile variations with water deficits along different parts of two varieties of Catharanthus roseus. Colloid Surf. B 2008, 62, 312-318. [CrossRef]

49. Bahadori, F.; Topçu, G.; Boğa, M.; Türkekul, A.; Kolak, U.; Kartal, M. Indole alkaloids from Vinca major and V. minor growing in Turkey. Nat. Prod. Commun. 2012, 7, 731-734. [CrossRef]

50. Barrales-Cureño, H.J.; Reyes, C.R.; García, I.V.; Valdez, L.G.L.; De Jesús, A.G.; Cortés Ruíz, J.A.; Sánchez Herrera, L.M.; Calderón Caballero, M.C.; Magallón, J.A.S.; Espinoza Perez, J.; et al. Alkaloids of pharmacological importance in Catharanthus roseus. In Alkaloids-Their Importance in Nature and Human Life; Kurek, J., Ed.; Intech Open Ltd.: London, UK, 2019; Volume 1, p. 18.

51. Verma, P.; Mathur, A.K.; Shanker, K. Enhanced vincamine production in selected tryptophan-overproducing shoots of Vinca minor. Plant Cell Tiss. Org. Cult. 2012, 111, 239-245. [CrossRef]

52. O'Connor, S.E. Alkaloid biosynthesis. Wiley Encycl. Chem. Biol. 2008, 1, 17-33. [CrossRef]

53. Yin, H.; Sun, Y.-H. Vincamine-producing endophytic fungus isolated from Vinca minor. Phytomedicine 2011, 18, 802-805. [CrossRef]

54. Liu, Z.; Wu, H.-L.; Li, Y.; Gu, H.-W.; Yin, X.-L.; Xie, L.-X.; Yu, R.-Q. Rapid and simultaneous determination of five Vinca alkaloids in Catharanthus roseus and human serum using trilinear component modeling of liquid chromatography-diode array detection data. J. Chromat. B 2016, 1026, 114-123. [CrossRef]

55. Mierziak, J.; Kostyn, K.; Kulma, A. Flavonoids as important molecules of plant interactions with the environment. Molecules 2014, 19, 16240-16265. [CrossRef] [PubMed]

56. Choi, Y.H.; Tapias, E.C.; Kim, H.K.; Lefeber, A.W.M.; Erkelens, C.; Verhoeven, J.T.J.; Brzin, J.; Zel, J.; Verpoorte, R. Metabolic discrimination of Catharanthus roseus leaves infected by Phytoplasma using 1H-NMR spectroscopy and multivariate data analysis. Plant Physiol. 2004, 135, 2398-2410. [CrossRef] [PubMed]

57. Liu, X.; Vrieling, K.; Klinkhamer, P.G.L. Interactions between plant metabolites affect herbivores: A study with pyrrolizidine alkaloids and chlorogenic acid. Front. Plant Sci. 2017, 8. [CrossRef] [PubMed]

58. Wu, L.; Ye, M.; Zhang, J. Vincamine prevents lipopolysaccharide induced inflammation and oxidative stress via thioredoxin reductase activation in human corneal epithelial cells. Am. J. Transl. Res. 2018, 10, 2195-2204. [PubMed]

59. Stagos, D. Antioxidant activity of polyphenolic plant extracts. Antioxidants 2020, 9, 19. [CrossRef] [PubMed]

60. Grujić, S.M.; Radojević, I.D.; Vasić, S.M.; Čomić, L.R.; Topuzović, M.D. Antimicrobial activity and some phytochemical analysis of two extracts Vinca minor L. Krag. J. Sci. 2014, 3, 145-154. [CrossRef]

61. Șimșek Sezer, E.N.; Uysal, T. Volatile and phenolic compositions of the leaves of two Vinca L. species from Turkey. Curr. Perspect. Med. Arom. Plants 2018, 1, 103-110.

62. Özçelik, B.; Kartal, M.; Orhan, I. Cytotoxicity, antiviral and antimicrobial activities of alkaloids, flavonoids, and phenolic acids. Pharm. Biol. 2011, 49, 396-402. [CrossRef] [PubMed]

63. Adamczak, A.; Ożarowski, M.; Karpiński, T.M. Antibacterial Activity of Some Flavonoids and Organic Acids Widely Distributed in Plants. J. Clin. Med. 2020, 9, 109. [CrossRef] [PubMed]

64. Dubey, S.; Ganeshpurkar, A.; Bansal, D.; Dubey, N. Experimental studies on bioactive potential of rutin. Chron. Young Sci. 2013, 4, 153-157. [CrossRef]

65. Suwalak, S.; Voravuthikunchai, S.P. Morphological and ultrastructural changes in the cell structure of enterohaemorrhagic Escherichia coli O157:H7 following treatment with Quercus infectoria nut galls. J. Electron Microsc. 2009, 58, 315-320. [CrossRef] [PubMed]

66. Aruldass, C.A.; Marimuthu, M.M.; Ramanathan, S.; Mansor, S.M.; Murugaiyah, V. Effects of Mesua ferrea Leaf and Fruit Extracts on Growth and Morphology of Staphylococcus aureus. Microsc. Microanal. 2013, 19, 254-260. [CrossRef] [PubMed]

67. Gupta, A.; Mahajan, S.; Sharma, R. Evaluation of antimicrobial activity of Curcuma longa rhizome extract against Staphylococcus aureus. Biotechnol. Rep. 2015, 6, 51-55. [CrossRef] 
68. Khanavi, M.; Pourmoslemi, S.; Farahanikia, B.; Hadjiakhoondi, A.; Ostad, S.N. Cytotoxicity of Vinca minor. Pharm. Biol. 2010, 48, 96-100. [CrossRef] [PubMed]

69. Amos, L.A. What tubulin drugs tell us about microtubule structure and dynamics. Semin. Cell Dev. Biol. 2011, 22, 916-926. [CrossRef]

70. Khattak, S.; Khan, H. Anti-cancer potential of phyto-alkaloids: A prospective review. Curr. Cancer Ther. Rev. 2016, 12, 66-75. [CrossRef]

71. Zhu, W.; Gao, J. The Use of Botanical Extracts as Topical Skin-Lightening Agents for the Improvement of Skin Pigmentation Disorders. J. Invest. Dermat. Symp. Proceed. 2008, 13, 20-24. [CrossRef] [PubMed]

72. Arunkumar, R.; Abraham, A.N.; Shukla, R.; Drummond, C.J.; Greaves, T.L. Cytotoxicity of protic ionic liquids towards the HaCat cell line derived from human skin. J. Mol. Liq. 2020, 314, 113602. [CrossRef]

73. Danciu, C.; Zupko, I.; Bor, A.; Schwiebs, A.; Radeke, H.; Hancianu, M.; Cioanca, O.; Alexa, E.; Oprean, C.; Bojin, F.; et al. Botanical Therapeutics: Phytochemical Screening and Biological Assessment of Chamomile, Parsley and Celery Extracts against A375 Human Melanoma and Dendritic Cells. Int. J. Mol. Sci. 2018, 19, 3624. [CrossRef]

74. Andreicut, A.-D.; Pârvu, A.E.; Mot, A.C.; Pârvu, M.; Fischer Fodor, E.; Cătoi, A.F.; Feldrihan, V.; Cecan, M.; Irimie, A. Phytochemical analysis of anti-inflammatory and antioxidant effects of Mahonia aquifolium flower and fruit extracts. Oxid. Med. Cell Longev. 2018, 2018. [CrossRef]

75. Farcaș, A.D.; Moț, A.C.; Zăgrean-Tuza, C.; Toma, V.; Cimpoiu, C.; Hosu, A.; Pârvu, M.; Roman, I.; Silaghi-Dumitrescu, R. Chemo-mapping and biochemicalmodulatory and antioxidant/prooxidant effect of Galium verum extract during acute restraint and dark stress in female rats. PLoS ONE 2018, 13. [CrossRef] [PubMed]

76. Sreevidya, N.; Mehrotra, S. Spectrophotometric method for estimation of alkaloids precipitable with Dragendorff's reagent in plant materials. J. AOAC Int. 2003, 86, 1124-1127. [CrossRef]

77. Blainski, A.; Lopes, G.C.; de Mello, J.C.P. Application and analysis of the Folin Ciocâlteu method for the determination of the total phenolic content from Limonium brasiliense L. Molecules 2013, 18, 6852-6865. [CrossRef] [PubMed]

78. Pękal, A.; Pyrzynska, K. Evaluation of aluminium complexation reaction for flavonoid content assay. Food Anal. Met. 2014, 7, 1776-1782. [CrossRef]

79. Alam, M.N.; Bristi, N.J.; Rafiquzzaman, M. Review on in vivo and in vitro methods evaluation of antioxidant activity. Saudi Pharm. J. 2013, 21, 143-152. [CrossRef] [PubMed]

80. Mot, A.C.; Bischin, C.; Mureșan, B.; Pârvu, M.; Damian, G.; Vlase, L.; Silaghi-Dumitrescu, R. Antioxidant activity evaluation by physiologically relevant assays based on haemoglobin peroxidase activity and cytochrome c-induced oxidation of liposomes. Nat. Prod. Res. 2016, 30, 1315-1319. [CrossRef]

81. Carpa, R.; Dragan-Bularda, M.; Muntean, V. General Microbiology. Practical Guide; Presa Universitara Clujeana: Cluj-Napoca, Romania, 2014; pp. 58-61.

82. Leclercq, R.; Canton, R.; Brown, D.F.J.; Giske, C.G.; Heisig, P.; MacGowan, A.P.; Mouton, J.W.; Nordmann, P.; Rodloff, A.C.; Rossolini, G.M.; et al. EUCAST expert rules in antimicrobial susceptibility testing. Clin. Microbiol. Infect. 2013, 19, 141-160. [CrossRef]

83. Erlandsen, S.L.; Kristich, C.J.; Dunny, G.M.; Wells, C.L. High-resolution visualization of the microbial glycocalyx with low-voltage scanning electron microscopy: Dependence on cationic dyes. J. Histochem. Cytochem. 2004, 52, 1427-1435. [CrossRef] [PubMed]

84. Macavei, S.G.; Suciu, M.; Craciunescu, I.; Barbu-Tudoran, L.; Tripon, S.C.; Leostean, C.; Balan, R. SPION size dependent effects on normal and cancer cells. Stud. Univ. Babes Bolyai Biol. 2017, LXII, 29-42. [CrossRef]

85. Hayat, M.A. Principles and Techniques of Electron Microscopy. Biological Applications, 4th ed.; Cambridge University Press: Cambridge, UK, 2000. 